\title{
An Interrogation of Habermas' Moral Politics: Evacuation of 'the Political'
}

by

Aysegul Ergul

A thesis submitted to the Faculty of Graduate Studies in partial fulfillment of the requirements for the degree of Masters of Arts in the Institute of Political Economy

\author{
Carleton University \\ Ottawa. Ontario \\ (C) Copyright Aysegul Ergul \\ 2005
}




$\begin{array}{ll}\begin{array}{l}\text { Library and } \\ \text { Archives Canada }\end{array} & \begin{array}{l}\text { Bibliothèque et } \\ \text { Archives Canada }\end{array} \\ \begin{array}{l}\text { Published Heritage } \\ \text { Branch }\end{array} & \begin{array}{l}\text { Direction du } \\ \text { Patrimoine de l'édition }\end{array} \\ \begin{array}{l}\text { 395 Wellington Street } \\ \text { Ottawa ON K1A ON4 }\end{array} & \begin{array}{l}\text { 395, rue Wellington } \\ \text { Ottawa ON K1A ON4 } \\ \text { Canada }\end{array}\end{array}$

Your file Votre référence

ISBN: 0-494-10042-7

Our file Notre référence

ISBN: 0-494-10042-7

NOTICE:

The author has granted a nonexclusive license allowing Library and Archives Canada to reproduce, publish, archive, preserve, conserve, communicate to the public by telecommunication or on the Internet, loan, distribute and sell theses worldwide, for commercial or noncommercial purposes, in microform, paper, electronic and/or any other formats.

The author retains copyright ownership and moral rights in this thesis. Neither the thesis nor substantial extracts from it may be printed or otherwise reproduced without the author's permission.
AVIS:

L'auteur a accordé une licence non exclusive permettant à la Bibliothèque et Archives Canada de reproduire, publier, archiver, sauvegarder, conserver, transmettre au public par télécommunication ou par l'Internet, prêter, distribuer et vendre des thèses partout dans le monde, à des fins commerciales ou autres, sur support microforme, papier, électronique et/ou autres formats.

L'auteur conserve la propriété du droit d'auteur et des droits moraux qui protège cette thèse. $\mathrm{Ni}$ la thèse ni des extraits substantiels de celle-ci ne doivent être imprimés ou autrement reproduits sans son autorisation.
In compliance with the Canadian

Privacy Act some supporting forms may have been removed from this thesis.

While these forms may be included in the document page count, their removal does not represent any loss of content from the thesis.
Conformément à la loi canadienne sur la protection de la vie privée, quelques formulaires secondaires ont été enlevés de cette thèse.

Bien que ces formulaires aient inclus dans la pagination, il n'y aura aucun contenu manquant.

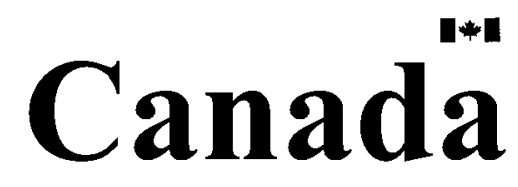




\begin{abstract}
My thesis is an attempt to understand the reasons of the decline of 'the political' and to think about the possibility of an agonistic project of radical politics that goes beyond the limits of the liberal democracy. With this purpose in mind, I analyzed Habermas' theory of communicative action in relation to his discourse ethics, which constitutes one of the most significant critiques of the moral and political theory of liberalism in contemporary political theory as an endeavor to strengthen the role of the public sphere. Even though Habermas criticizes the one-sided rationalization of modern society and develops a dialogical notion of reason via his theory of communicative action, this intersubjectivity or mutual recognition within the public sphere remains abstract since he separates morality from ethics and conceptualizes 'the political' on the basis of formal principles grounded solely in the constraints of an unsituated reason. Against Habermas' 'consensus-oriented' conceptualization of 'the political,' this thesis argues for an agonistic conception of 'the political' founded on Arendt's theory of action and judgment.
\end{abstract}


Dedicated to Simten Coşar

iii

Reproduced with permission of the copyright owner. Further reproduction prohibited without permission. 


\section{Acknowledgements}

I would like to thank my supervisor, Professor Alan Hunt, for his critical guidance and patience, and Professor Peter Swan for his recommendations. I am grateful to Professor Peter Emberley for lighting my path towards Hannah Arendt while I was lost within Habermas' abstract world.

I would like to thank also to Simten Cosar to whom I dedicated my thesis. Her encouragement, unrelenting support and friendship continuous to play a significant role in my academic endeavors, and without her guidance I could not have been where I am.

I would like to thank Donna Coghill for her support. Since the first day I arrived at the Institute of Political Economy, she put all her effort to help all of us as well as lightened our days with her smile.

Finally, I would like to thank my family and friends for their support, patience and encouragement without which, I could not have completed this thesis. 
Abstract

Acknowledgements iv

$\begin{array}{ll}\text { Introduction } & 1\end{array}$

Chapter One: The Critique of One-Sided Rationalization of Modernity

1.1 The Transformation of the Epistemology of Scientific Knowledge

1.2 The Concept of the Lifeworld and the Uncoupling of The Lifeworld and System

1.3 The Cost of Modernity: 'Colonization of the Lifeworld'

Chapter Two: Habermas' Reconceptualization of 'the Political': Procedural Restatement of Liberal 'Rule of Law'

2.1 Theory of Discourse Ethics: 'Moral Politics'

2.1.1 The Principle of Moral Argumentation

2.1.2 The Philosophical Justification of the

Principle of Universalizability

2.2 The Internal Relation between Law and Politics 43

2.3 On the Employment of Practical Reason

49

2.4 Deliberative Politics: A Procedural Concept of Democracy

2.5 Imprisonment of 'the Political' in the Formal Logic of Legislation

Chapter Three: An Alternative to 'Moral Politics' From an Arendtian Perspective

3.1 The Public Realm

3.2 The Light of the Public Sphere: The Construction of Plurality and Freedom

3.3 Intertwining of Ethics and Politics in Arendt's Political Thought 


\section{Introduction}

What necessarily exists in all communities of any degree of complexity is 'the political' since all of them organize themselves in accordance with certain principles of justice, equality, and authority. In this sense, 'the political' is fundamentally constitutive of our lives; indeed, it identifies what is distinctively human. This is the reason why Aristotle defines man as zoon politikón, as a political animal, who is capable of deliberation. To be able to deliberate means that we, humans, exist in a polity and we are capable of persuading each other via deliberation. We are, in turn, capable of forming a system of values and of principles amongst ourselves in order to actualize our potential of freedom inherent in our birth. In this vein, 'the political' acquires a fundamental place in the human condition. However, particularly today, we live in a moment of the decline of 'the political.' We live in a period in which 'the political' is understood as strategic bargaining of various games. We live in a period in which the majority of people think of freedom as essentially freedom from politics or politics as the centralized regulation of the needs of life. We live in a period in which freedom is confined to the private sphere, and the ideas of justice, equality, public good and so on are exiled. Unfortunately, it has been forgotten that individual freedom can only be actualized through collective political action.

Nowadays, we confront a growing political apathy, and a dehumanization of the public sphere. If we begin to inquire about the roots of this growing apathy, we do not need to look further than the seventeenth century, the century in which 'independence of the human mind' was declared. It is the century that heralds the age of modernity which coincides with the emergence of a modern liberal state. It is the age of modernity in which the public sphere of action and speech are replaced by bureaucratic administration, 
in which freedom is reduced to private interest and individual achievements at the expense of human togetherness, and where morality and ethics are separated from politics in favor of a 'neutrality' of the state. By lauding and endorsing conformity, and dehumanizing the public sphere, modernity and the liberal democratic state have embodied the idea that there is no, at best, very little that people can change in the way human affairs are being run in the world-indeed, the idea promoted is that 'there is no need for such a change.' The coincidence of such a loss of human ability to imagine a better world with the growth of individual freedom generates the privatization of "the political' and it recedes into the 'intimate.' Thus, 'the political' has vanished in the stories of individuals' personal benefits and losses and, in turn, the public sphere is restricted to the matters of 'ruling' and 'ruling mechanisms,' i.e. state.

My thesis is an attempt to understand the reasons of the decline of 'the political' and to think about the possibility of an agonistic project of radical politics that goes beyond the limits of the liberal democracy. With this purpose in mind, I analyzed Habermas' discourse ethics, which constitutes one of the most significant critiques of the moral and political theory of liberalism in contemporary political theory as an endeavor to strengthen the role of the public sphere. ${ }^{1}$ Habermas attributes the decay of the public realm to the one-sided rationalization of modern society that generates the colonization of the lifeworld' by system mechanisms and the 'cultural impoverishment' of society. $\mathrm{He}$ suggests the reconstruction of the public realm as a ground of critique on the basis of 'reflective communicative action' which is capable of disclosing the ideal of 'undistorted

1 In my thesis, I specifically concentrated on Habermas' discourse ethics because his conceptualization of "the political" is shaped on the basis of discourse. In this sense, Habermas' political theory is called "moral politics," while his moral theory is named "political morality." In order to prevent confusion of concepts, it is worth noting that Habermas uses 'discourse' and 'argumentation' interchangeably and they refer to the moment where communicative action transforms to a 'reflective' communicative action. 
communication' shaped by discourse ethics. Enframing the argumentation process through moral principles, namely, the principle of discourse and the principle of universalizability, he draws boundaries for the public sphere that demonstrate 'what' can enter into this process and 'how' its validity can be tested. This relation between morality and politics is supported by institutionalized procedures of legitimate lawmaking which transform the public opinion into binding decisions.

Even though Habermas criticizes the one-sided rationalization of modern society and develops a dialogical notion of reason via his theory of communicative action, this intersubjectivity or mutual recognition within the public sphere remains abstract since he separates morality from ethics and conceptualize 'the political' in the light of moral principles. More specifically, Habermas' endeavor to reformulate Kant's intelligible moral agent in a dialogical sense by reference to the ontogenesis of speaker and world perspectives that leads to a decentred understanding of the world, which cannot go beyond the liberal notion of 'the political'; rather it reproduces the abstractness of the modern autonomous subject and the unavoidable emptiness of formal principles grounded exclusively in the constraints of an unsituated reason. My argument is that the emergence of Habermas' public sphere is, in the strict sense of the term, a 'utopia' since it presupposes the adaptation of decentralized consciousness with respect to moral principles by all participants joined the argumentation process. Yet, what is more important for me is the potential threat of the inner logic of this utopia for the concept of 'the political' since it centrally depends on the idea of adapting decentralized consciousness, rather than differences and distinctiveness of individuals. This reductionist definition of 'the political' emasculates the public sphere and, in turn, it 
disables individuals to imagine a better world as is the case for the liberal notion of the public sphere.

It is my contention that, in Habermas' account, there is no place in the public sphere for the questions about the meaning of life which makes individuals 'feel at home on earth' regardless of their mortal lives, because, Habermas claims, we live in a world where "everything solid melted into air." His conceptualization of 'the political' therefore does not attribute any priority to the public sphere-it is a sphere neither for the selfrealization of individuals nor for the creation of common meaning in the political life; rather, it solely relies on its functionality for social and system integration parallel to the other spheres of institutional framework of 'the lifeworld,' i.e. economy, administration, and family. This interpretation of 'the political' bereaves the potentiality of the public sphere to create a realm that "relates and separates men at the same time."2 Hence, it is functionalized simply in favor of reaching an agreement. In this sense, it can be argued that he derives his concept of 'the political' from within 'the social' whose concern is to obtain 'no-man's rule' which can be actualized through the telos of purely communicative politics, namely, 'reaching an agreement.' In doing so, he not only propagates an instrumental notion of 'the political' but also demeans plurality and generates conformity in the public sphere. This instrumentalization of 'the political' is also recreated at the individual level, to the fact that if the public sphere is not a realm in which individuals form and manifest themselves, the only reason for individuals to enter into the public sphere would be their self-interests and demands for new rights. This is the point where Habermas' insufficiency to surmount the egocentric notion of 'the political' becomes evident.

${ }^{2}$ Hannah Arendt, The Human Condition (Chicago: University of Chicago Press, 1958) (second edition), p. 52. 
All in all, I think, Habermas' conceptualization of 'the political' with respect to morality to provide a peculiar protection for socialized individuals within communicative forms of life predicates a stable political system, which is protected and guaranteed by the rule of law. Thus, he closes the doors of the public sphere to contingency, ruptures, or more accurately, to the unpredictable and boundless character of political action. Indeed, this is the reason for him to warn individuals to peel away their identities before they enter into the public sphere and adapt a moral point of view. In doing so, he sacrifices plurality and openness of the public realm in favor of conformity and stability.

Habermas' limited conceptualization of 'the political' can be robustly challenged from an Arendtian point of view which alters not only to a teleological, but also to an egocentric notion 'the political.' What makes Arendt peculiar for this thesis is her agonistic notion of 'the political' through which ethics and politics are intertwined. In this sense, the public sphere is understood as a common world in which individuals form and manifest themselves; it is a sphere in which the 'great and radiant' are brought forth via political action and speech; it is a sphere where the meaning of the 'world in common' is created and recreated through power; it is a sphere which is a home for mortal human beings whereby they can partially experience immortality. In her claim, she suggests that the active engagement of individuals in the creation and recreation of the 'world in common' provide them not only the experience of public freedom and the joys of public happiness, but also a sense of political agency and efficacy. In other words, the participation of an individual to politics is not simply as a matter of political duty, or of personal interest, but of revealing reveal 'who somebody is' as distinct from 'what somebody is' which signifies a dialectical relation between individuality and communality. That is to say, by acting in the public sphere, individuals become aware of 
their potential to create a change, "to call something into being which did not exist before, which was not given, not even as an object of cognition or imagination," namely, to actualize a potential 'to start something new' inherent in our birth. ${ }^{3}$ Since each action is divided into two parts in Arendt's account - to begin and to set into motion-this beginning made by a single person can only be borne by participation of many. ${ }^{4}$ In this respect, I believe that individuality and communality condition each other within Arendt's concept of 'the political.'

At this point, it can be said that, in Arendt's view, Habermas' rational agents who enter into the public sphere in favour of their self-interests, and who suddenly turn into moral agents, through a magic trick, by peeling away their identities and liberating themselves from their interests, are replaced by political subjects who enter into the public sphere to disclose their uniqueness, or to reveal 'who they are.' This indicates an essential difference between Arendt and Habermas. I think that their experiences of witnessing totalitarian regimes affected their conceptualization of 'the political.' Obviously, their own experiences led them to different positions. Since Habermas is convinced that the experience of Holocaust stemmed from an insufficiency of institutions to protect human freedom and an unpredictability of action he establishes his public sphere as a realm which is "institutionally protected and procedurally defined." Then, he portrays this public sphere as a precondition of the argumentation process by encompassing the public sphere through visible and invisible walls: laws and intuitive knowledge of moral principles respectively. While he stresses enforcing power and significant role of institutions and law, he neglects their potential to create a tyranny of bureaucracy as is the case in liberal democracy. Despite her experience, Arendt does not

\footnotetext{
${ }^{3}$ Hannah Arendt, "What is Freedom?" in Between Past and Future: Eight Exercises in Political Thought (New York: Viking Press, 1961), p. 151.

${ }^{4}$ Arendt, op. cit., supra note 2, pp. 188-190.
} 
lose her confidence in human action and its transgressive potential; in contrast to Habermas, she conceptualizes 'the political' by reference to a conditioning relation between action, politics, and freedom. Arendt is like-minded with Habermas in the sense that human artefacts, i.e. institutions and law, can set boundaries and limitations to existing human affairs; however, she recognizes their limited character in the face of unpredictability and boundlessness of action. For her, the virtue of moderation 'of keeping within bounds' is more effective than safeguarding of the rule of law. Furthermore, in Arendt's account, the criteria of judgment within the public sphere does not rely on assumed principles of discourse, but to a 'common sense,' the idea of a 'public sense,' which creates a possibility for our opinions to go beyond the limits of a particular viewpoint and to encompass the viewpoints of others. Therefore, unlike Habermas, at the end Arendt does not attribute any telos to 'the political.' For her, it has an autonomous place regarding human condition which should not be intervened by 'the social. 


\section{Chapter 1}

\section{The Critique of One-Sided Rationalization of Modernity}

"Where ends are agreed, the only questions left are means, and these are not political but technical."

Isaac Berlin

"Man imagines himself free from fear when there is no longer anything unknown ...Enlightenment is mythic fear turned rational."

Adorno and Horkheimer

In the contemporary world, the conceptualization of 'the political' cannot be detached from questions of modernity since 'the political,' in the modern epoch, has undergone a considerable change through the process of rationalization. Habermas is one of the most distinctive philosophical figures in the contemporary world to illuminate both the pathologies and achievements of modernity at the political, societal, cultural and personal levels. Against the delineation of modernity as a wasted epoch, Habermas propagates a sophisticated defense imbued with the normative potential which he sees inherent in modernity. Crucial to that effort is the paradigm shift from the "philosophy of consciousness' to the 'paradigm of language' in Habermas' account.

The theoretical framework of my thesis incorporates Habermas' characterization of modernity as an 'unfinished project' which not only provides the means to understand the depoliticization process of liberal democracy, but also sheds light on the communicative side of the rationalization process as an unrealized normative content of modernity, which differentiates him from his predecessors. In this sense, by clarifying Habermas' delineation of the rationalization process of modernity, and by examining his 
modernity, and by examining his analysis of the 'colonization of the lifeworld' and 'cultural impoverishment,' I want to demonstrate how modernity has prevented its own potentiality to create both private and public autonomy in Habermas' account. It is my contention that Habermas' conceptualization of 'communicative rationality' as other side of the rationalization process of modernity is a spring of hope for the unfinished modern project.

\subsection{The Transformation of the Epistemology of Scientific Knowledge:}

The concept of 'the political' and the philosophical examination of the realm of action (practical philosophy) have been transformed drastically since the Ancien Regime. This transformation essentially originated from the shift within scientific knowledge, and in turn, created the separation of ethics and morality from politics. In order to specify the features of this shift, Habermas indicates three main differences between the Aristotelian notion of 'the political' and the modern concept of 'the political. ${ }^{1}$ First, there is a significant shift within scientific knowledge from phronēsis (practical knowledge) to theōria (theoretical knowledge), which indicates a pivotal rupture from philosophia practica grounded in the Aristotelian epistemology of science whose object is human action. ${ }^{2}$ By referring to a different epistemological status of scientific disciplines, Aristotle distinguishes theōria from phronēsis, the former representing unchanging realities of which we can have universal knowledge and the latter signifying praxis (action), the changing social situations in which our

\footnotetext{
' Jürgen Habermas, "The Classical Doctrine of Politics in Relation to Social Philosophy," in Theory and Practice, John Viertel (trans.) (Boston: Beacon Press, 1973), p. 42.

${ }^{2}$ Franco Volpi, "The Rehabilitation of Practical Philosophy and Neo-Aristotelianism," in Action and Contemplation: Studies in the Moral and Political Thought of Aristotle, Robert C. Bartlett and Susan D. Collins (eds.) (New York: State University of New York Press, 1999), p. 11.
} 
actions unfold. Practical knowledge whose subject matters are the Just and the Excellent, in other words, politics and ethics, cannot attain a high level of certainty or generality because it is directed towards the concrete situation to comprehend the circumstances in their contingent and infinite variety. Therefore, theoretical cognition of universal truths has rigorously limited their relevance for practical reflection.

The predecessors of the Enlightenment thought such as Bacon and Descartes aim at surmounting the contingent and uncertain character of human knowledge. For Descartes, no less than Bacon, certain knowledge is not possible for 'natural reason.' "What is required is ... a 'method' of inquiry," which "begins with an intellectual purge" 3 since they believe in an open mind, free from prejudice, habit, experience, and tradition as much as free as possible, free from desires of body. The trust of rationalists in the authority of unhindered reason motivates them to remove all sense of rhythm and continuity from intellect and dissolve them into "a succession of climacterics, each to be surmounted by tour de raison." ${ }^{4}$ The paradigm of knowledge represented by this mathematical method has two implications: on the one hand, science has been grounded in theoretical knowledge which is based on abstractions and directed to the search for an objective truth, and in this context, 'method,' or 'technique of inquiry' is seen as a guarantor of universality and scientific rigidity. On the other hand, "human action is accepted as an object of knowledge, not in the sense that it is concretely guided by that

\footnotetext{
${ }^{3}$ Michael Oakeshott, "Rationalism in Politics," in Rationalism and Politics and Other Essays (London: Methuen \& Co Ltd., 1962), pp. 15-16.

${ }^{4}$ Ibid., p. 3. Oakeshott reminds us that Descartes, as distinct from Bacon, acknowledges that it could be an error to conceive the method as the sole means of inquiry because he knows that the infallible and universal method he presented is modeled on geometry whose limitations become apparent when it is applied to things, not to possibilities.
} 
knowledge, but in the sense that it is accepted as the field of a possible exercise of knowing." In other words, human actions are to be regarded as a field of the object of the descriptive examination in order to reach universal principles and truth. The implications of such rationalism to political theory become visible in the writings of Thomas Hobbes. The Leviathan in which he attempts to provide a "crib to politics" establishes "once and for all the conditions of the correct order of the state and society as such."6 Such belief in correctly calculated rules, relationships, and institutions of state and society generates 'the politics of uniformity;' because an outline of a system that does not recognize circumstances cannot have any place for variety. $^{7}$ Consequently, with the beginning of the modern period, the classical notion of 'the political' which recognized an infinite variety and contingency of circumstances is replaced by the modern notion of 'the political' which claims to be universal and certain by means of technique.

Such emphasis on technique recalls Aristotle's differentiation of poiēsis (making) and the knowledge pertaining to it, techne (technical knowledge), from praxis and phronēsis. While poiêsis is concerned with "bringing something into being" or the product, which "is not an end in itself but only a relative or particular end," praxis is concerned with action, which "is an end, and the object of appetition." Since Aristotle defines praxis as an end in itself-that is to say, acting well and living well-phronēsis must be inculcated via education and practical experience and maintained through a coherent personality, rather than an

\footnotetext{
${ }^{5}$ Volpi., op. cit., supra note 2, p. 8.

${ }^{6}$ Habermas, op. cit., supra note 1, p. 43. Emphases are added.

${ }^{7}$ Oakeshott, op. cit., supra note 3, p. 6.

${ }^{8}$ Aristotle, The Ethics of Aristotle (The Nicomachean Ethics), J. A. K. Thomson (trans.) (New York: Penguin Books, 1979), pp. 205-208.
} 
intellectual insight. From this point of view, the ethical character of human action cannot be separated from customs, tradition, and laws of the polis since it provides a sphere in which citizens find the best possible form of life. In other words, politics is seen as "a continuation of ethics." Nevertheless, with modernity, 'the political' becomes a matter of the 'felt need,' which is not qualified by practical knowledge of permanent interests and direction of society's movement, but it is interpreted by 'reason' and satisfied according to technique rather than prudential action of human beings toward each other. ${ }^{9}$ Thus, the translation of knowledge into practice becomes a technical problem. If you have knowledge of general conditions for a correct order of the state and society, the only thing that needs to be done is to perform "the correctly calculated generation of rules, relationships, and institutions" 10 since the rules are universal and valid for every situation. With the idea of applying knowledge, which is as rigid as mathematical knowledge, to ethics, politics, law, and economics, the corresponding knowledge loses its practico-moral dimension which is capable of guiding action. "This separation of politics from

\footnotetext{
${ }^{9}$ Oakeshott, supra note 3, p. 22.

${ }^{10}$ Habermas, op. cit., supra note 1, p. 43.

${ }^{11}$ It is worth noting here that this modern project encountered critiques in the eighteenth and nineteenth centuries. The first robust critique was raised by Jean-Jacques Rousseau. He drew attention to sub-rational aspects of human nature and tried to surmount the distinction between mind and body. Subsequently, Immanuel Kant developed a critique the Cartesian rationality, which eliminates leading role of reason morally and practically. Kant distinguished the examination of man as a being who belongs to the order of nature from the examination of man as a being who belongs to the order of freedom. This differentiation generated his distinction between the metaphysics of nature, which aims at determining the laws of nature as an object of experience, and the metaphysics of morals, which aims at determining the laws of human will. By describing the metaphysics of morals, he has attempted to show the morally guiding role of practical reason. However, Kant's claim to universality and his monological understanding of reason still reflect the effects of his rationalist predecessors. Early in the nineteenth century, by delineating the intrinsically historical and social character of the structures of consciousness, Hegel radically challenges the Cartesian paradigm and its subjectivistic orientation. Despite all
} 
morality replaces instruction in leading a good and just life with making possible a life of well-being within a correctly instituted order."12 Consequently, with modernity, 'the political' becomes a matter of engineering that provides the most effective means for solving the immediate problems in the light of technical knowledge. Hence, the tension between 'is' and 'ought' is eliminated from the sphere of 'the political,' and in turn, 'the political' is delimited to technical questions. In other words, questions about the ends of politics are excluded from the political sphere, and they are replaced by immediate problems in order to locate the most effective solution in the short-term.

The emergence of such rationalism has also changed the connotation of 'reason.' It has become "a faculty of calculation by which men conclude one thing from another and discover fit means of attaining given ends not themselves subject to the criticism of reason." ${ }^{\prime 13}$ This new understanding of reason has coincided with a new form of society which is based on a form of capitalist economic activity, bourgeois law, and bureaucratic authority. Max Weber introduces the concept of 'rationalization' in order to indicate the increasing penetration of such 'purposive rationality' into other areas of social life through the institutionalization of scientific and technological development. Contrary to the celebration of reason, Weber claims that this growing effect of 'purposive rationality' in turn, will spawn bureaucratization which will lead to a reification of social relationships and create an 'iron cage.' Following Weber, Adorno and Horkheimer argue that modern

these challenges, the Cartesian paradigm remained the main principal of modernity. Actually, it has proved its continuum by virtue of the development of logical empiricism in twentieth century.

${ }^{12}$ Ibid., p. 43.

${ }^{13}$ Oakeshott, supra note 3, p. 18. 
Western civilization has been successful in freeing itself from the constraints of the natural world through the increasing development of science and technology; nevertheless, it has not freed people from the chains as envisaged by Karl Marx. Rather, it has created ever more effective and subtle form of chains: 'chains of reason.' From the perspective of Adorno and Horkheimer, under the sign of 'instrumental rationality' that becomes autonomous by the means of the rationality of science and technology reason becomes the medium of social repression by intervening the social life. ${ }^{14}$

More succinctly, Habermas'approach to the rationalization process of modernity differs from Weber as well as Adorno and Horkheimer. According to Habermas, what happens in the course of modernization process is neither an irresistible expansion of purposive rationality to all spheres of life as Weber suggests nor history reaches its end as a total blindness engendered by instrumental rationality as Adorno and Horkheimer suppose. This gloomy characterization of the rationalization process could not detain him to oppose their pessimism in terms of its one-sidedness and stress the selectivity of rationalization in modernity. From Habermas' point of view, what Weber as well as Adorno and Horkheimer take as the basis of their analysis - the correspondence of instrumental action with instrumental rationality-is limited to 'subsystems of purposive-rational action,' which cannot explain the institutionalization of 'communicative rational action' within 'the lifeworld.' This in turn, fails to acknowledge the structural possibilities that were opened up with the process of rationalization.

\footnotetext{
${ }^{14}$ Jürgen Habermas, The Theory of Communicative Action, Vol. I., Thomas McCarthy (trans.) (Boston, Beacon Press, 1984), p. 144.
} 
In Habermas' view, the rationalization of action orientations and the institutional framework of a society or 'the lifeworld' structures are different from the expansion of rationality. Even though Weber identifies the rationalization process as an institutionalization of purposive-rational action with structural effects on society as a whole, he neglects the institutionalization of 'communicative-rational action' within the 'lifeworld.' In fact, there is an increasing communicative rationality in 'the lifeworld' that entails greater purposive rationality in the system. ${ }^{15}$ Now, new questions can be posed: Where do the pathologies of the modernization process such as loss of meaning, insecurity of collective identity, alienation, psycho-pathologies derive from? How does the critical and reflective structure of the bourgeois public sphere transfer into a drain desert, which describes the truth as black or white? Expressed differently, how does the sphere of freedom in which unconstrained communicative action is realized and the aim of this communicative action is defined as forming and maintaining an intersubjective space, become one of the means of domination? In order to answer these questions, I will attempt in the next section to explain the basis of Habermas' differentiation of 'the lifeworld' from system, and then I will try to clarify his re-conceptualization of rationality with reference to its association with the difference between 'the lifeworld' and system.

\footnotetext{
${ }^{15}$ Joannes Berger, "The Linguistification of the Sacred," in Communicative Action: Essay's on Jürgen Habermas's Theory of Communicative Action, Alex Honneth \& Hans Joas (eds.), Jeremy Gaines \& Doris L. Jones (trans.) (Cambridge: The MIT Press, 1991), p. 168.
} 


\subsection{The Concept of the Lifeworld and the Uncoupling of the Lifeworld and System}

Habermas develops a critical approach in both action theory and system theory ${ }^{16}$ In Theory of Communicative Action, he becomes convinced that society is neither can be a domain of symbolic interaction nor a domain of material reproduction. Therefore, he articulates the paradigm of lifeworld and system theory as two sides of the same coin in order to provide a more comprehensive explanation and understanding of the pathologies of modern society. ${ }^{17}$ As a result, Habermas develops a two-stage concept of society: society as a lifeworld and as a system. ${ }^{18} \mathrm{He}$ supports his conceptual framework of society with the theory of social evolution that differentiates the rationalization of 'the lifeworld' (Lebenswelt) from the increasing complekityhoflthensesiahsystem, 'the lifeworld' can be represented by "culturally transmitted and linguistically organized stock of interpretive patterns." ${ }^{\prime 19}$ It is the 'unthematized background of meaningfulness' through which human actions find their objective, subjective and normative reference points. To put it differently, 'the lifeworld' is "a reservoir of taken-for-granteds, of unshakable convictions" which is

\footnotetext{
${ }^{16}$ In Legitimation Crisis (1976), Habermas starts to develop his critical perspective about system theory. In this book he also makes a distinction between social integration and system integration leading to a differentiation in the concept of society in itself in his later writings. For more details see Jürgen Habermas, Legitimation Crisis, Thomas McCarthy (trans.) (Boston: Beacon Press, 1976).

${ }^{17}$ It is worth noting that Habermas develops the contrast between system and 'the lifeworld' in two distinct senses. On the one hand, he differentiates them in the sense of two different methodologies for the study of societies. The former represents an 'objectivating' and 'externalist' perspective, while the latter represents the 'hermeneutical' and 'internalist' understanding of societies. On the other hand, he distinguishes them as different kinds of institutions of societies. In my thesis, I will not focus on his first differentiation drawn from difference of methodologies, but I will pay attention to the differentiation in accordance with different kinds of institutions because I primarily concentrate on his discourse ethics and political theory in the sense of their relation to his notion of 'the political' rather than his critical social theory.

${ }^{18}$ Jürgen Habermas, Theory of Communicative Action, Vol. II., Thomas McCarthy (trans.) (Boston, Beacon Press, 1987), p. 120.

${ }^{19}$ Ibid., p. 124.
} 
handed down by culture and language. In this sense, culture is delineated as 'a stock of knowledge,' while language is defined as 'a medium' for the process of 'reaching understanding. ${ }^{, 20}$ In Habermas' view, 'the lifeworld' forms the institutional framework of communicative action situations of participants which they cannot step outside. It is reproduced by various functions of communicative action such as the renewal of knowledge, the formation of social solidarity and personal identity. Habermas states that

[u]nder the functional aspect of mutual understanding, communicative action serves to transmit and renew cultural knowledge; under the aspect of coordinating action, it serves social integration and establishment of solidarity; finally, under the aspect of socialization, communicative action serves the formation of personal identities. The symbolic structures of the lifeworld are reproduced by way of the continuation of valid knowledge, stabilization of group solidarity, and socialization of responsible actors. ${ }^{21}$

Thus, the structural components of 'the lifeworld'-culture, society, and personare reproduced by a medium of everyday communicative action. In turn, the reproduction processes of 'the lifeworld' are identified as cultural reproduction, social integration, and socialization, and they are actualized through communicative action..$^{2}$ the modern period, the development of scientific knowledge and the declaration of the authority of reason have devalued inherited religious,

\footnotetext{
${ }^{20}$ Ibid., pp. 124-125.

${ }^{21}$ Ibid., p. 137. Habermas integrates three different approaches into his conceptualization of the lifeworld: the phenomenological approaches of Husserl and Schutz with their emphasis on the production and reproduction of cultural knowledge, the social system approaches of Durkheim, Parsons and Luhmann with their emphasis on the functions of institutions, and social integration and solidarity, the symbolic interactionism of Mead with his expression of socialization process. For more details see Ibid., pp. 120-148. For short summary see James Craig Hanks, Refiguring Critical Theory: Jürgen Habermas and the Possibilities of Political Change (Boston: University Press of America, 2002), p. 78.

${ }^{22}$ Habermas, op. cit., supra note 18, pp. 137-141.
} 
philosophical, and moral truths and rules, to put it differently, "everything solid melts into air." Such reason and scientific knowledge pertaining to it rely on a critique of 'taken-for-granteds' and, therefore, they have given rise to the "detachment of moral-practical insights, of ethical and legal doctrines, of basic principles, of maxims and decision rules, from the world-views in which they are at first embedded." 23 As a result, 'the lifeworld' is subjected to structural transformations. Even though this rationalization process is portrayed as a 'banefulness' of modernity by his forerunners, Habermas interprets it not only as a process of 'loss of meaning' and 'loss of freedom' in Weberian terms, but also as a 'progress' leading to the development of new possibilities; for example, new forms of art, new understanding of democracy, and new aspects of freedom and individual autonomy. The basis of new possibilities, Habermas argues, stems from "the linguistification of the sacred in the domain of symbolic reproduction." ${ }^{24}$ In that case, what does "the linguistification of the sacred" actually mean? How does it occur? To respond these questions, we need to shed light on the way Habermas understands the structural transformation of 'the lifeworld' with reference to a differentiation of cultural value spheres and a differentiation of structures of consciousness. $^{25}$

In a Weberian sense, the rationalization of 'the lifeworld' represented by the decentred understanding of the world emanates the differentiation of cultural 'value spheres,' i.e. science and technology, morality and law, ethics and aesthetic each of

\footnotetext{
${ }^{23}$ Habermas, op. cit., supra note 14, p. 162.

${ }^{24}$ Berger, op. cit., supra note 15, p. 167.

${ }^{25}$ In the former, he adopts Weber's notion of cultural value spheres, while in the latter he applies Jean Piaget's notion of cognitive development.
} 
which has its own 'inner logic.' This leads to a differentiation of knowledge systems with reference to different validity claims; for instance, cognitive, normative and aesthetic. Habermas also tries to see the effect of 'disenchantment' at the individual level. This is where he discovers a structural parallelism between the experience of disenchantment and a shift from an 'egocentric' consciousness to a 'decentred' one. Disenchantment, he claims, thus denotes a breakdown of a 'sociocentric' consciousness and a construction of a decentred consciousness, recognizing demarcation between the natural, social and subjective worlds and their corresponding validity claims. He describes this change as a process of rationalization because it increases the learning capacity of humankind through providing actors conceptual means for developing a 'self-critical' perspective by which they can evaluate alternative interpretations of the case. This learning potential takes its definite shape in different forms of argumentation institutionalized in corresponding cultural spheres of action.

In this way, everyday communicative action, which was embedded in 'takenfor-granteds of the lifeworld,' is released from traditionally based institutions forcing the obligations of consensus, and relied on free 'public use of reason.' To put it somehow differently, the binding effects and normatively guiding role of the 'authority of unquestioned consensus' derived from traditional institutions are replaced by the 'authority of the better argument." ${ }^{26}$ Thus, the conditions of socialization and legitimation of political domination is altered, and in turn, the 'mechanism of reaching agreement' is loaded with a growing need of coordination.

${ }^{26}$ Habermas, op. cit., supra note 14, pp. 340-341. 
This is a principal reason for me to claim that Habermas considers the rationalization process as a 'reconstruction of the lifeworld.'

'The linguistification of the sacred' in the domain of symbolic reproduction is only one side of the rationalization process; the other side is the 'delinguistification of the forms of material reproduction. ${ }^{27}$ When a transition occurs from a normatively-secured pre-reflective and pre-given action contexts of the social integration to a discursive-will formation as an implication of the linguistification of the sacred, it engenders an overburdening of action coordination. Therefore, to protect social cohesion certain functions of material reproduction become split off from symbolic reproduction and they are transferred to two systematically integrated, specialized institutions: economy and administration. Habermas states that $\quad[\mathrm{m}]$ odern societies attain a level of system differentiation at which increasingly autonomous organizations are connected with one another via delinguistified media of communication: these systemic mechanisms steer a social intercourse that has been largely disconnected from norms and values, above all in those subsystems of purposive rational economic and administrative action that have become independent of their moral-political foundations. ${ }^{28}$

This development indicates the detachment of system and lifeworld from each other "in the sense that the complexity of the one and the rationality of the other grow."29 The former is corresponded to the systematically-integrated action contexts in which different agents coordinate their action with one another by functional operations and connection, whereas the latter is corresponded to the sociallyintegrated action contexts in which actions of agents are coordinated with one

\footnotetext{
${ }^{27}$ Berger, op. cit., supra note 15 , p. 167.

${ }^{28}$ Habermas, op. cit., supra note 18, p. 154.

${ }^{29}$ Ibid., p. 153.
} 
another by reference to a form of intersubjective consensus about norms, values, and ends. ${ }^{30}$ Habermas makes an analytical distinction between action-orientations, which rely on the distinction between action coordinating mechanisms: "actionoriented to success" and "action-oriented to reaching understanding." "Actionoriented to success" is categorized as instrumental action and strategic action. Instrumental action is action in a nonsocial action situation which utilizes technical rules in order to maximize the efficiency of its intervention into the complex action situations; whereas strategic action is action in social action situation that utilizes rules of rational choice in order to maximize its efficiency in influencing the decisions of the other via external means such as weapons or goods, threat or excitement. "In such cases, coordination of the subject's actions depends on the extent to which their egocentric utility calculations mesh." ${ }^{32}$ On the other hand, "in the communicative action one actor seeks rationally to motivate another by relying on the illocutionary

\footnotetext{
${ }^{30}$ Nancy Fraser, "What is Critical about Critical Theory? The Case of Habermas and Gender," New German Critique, 35, Special Issue on Jürgen Habermas (Spring-Summer, 1985), p. 102.

${ }^{31}$ The differentiation between "action-oriented to success" and "action-oriented to consensus" corresponds to a distinction between "strategic and instrumental rationality" and "communicative rationality" in the framework of Habermas' theory of communicative action. However, it should be noted here that Habermas also makes a distinction between "purposive rationality" and "communicative rationality" in the framework of theory of social evolution. I believe it is very important to acknowledge his treatment of the difference between "purposive rationality" and "communicative rationality" in order to surmount conceptual confusion Habermas' theoretical framework creates. In his theory of communicative action, the primary concern is to justify the typology of action that differentiates "action-oriented to success" from "action-oriented to reaching understanding" with reference to the distinction between action coordinating mechanisms. But, Habermas' concern primarily focuses on reproduction of society and the ways in which people engage with their environment in theory of social evolution. Therefore, the distinction between "purposive rationality" and "communicative rationality" is derived from the distinction between action structures: "labor" and "interaction." For more details see David Owen, Between Reason and History: Habermas and the Idea of Progress (Albany: State University of New York Press, 2002), pp. 17, pp. 35-37, 83.

${ }^{32}$ Jürgen Habermas, "Moral Consciousness and Moral Action," Moral Consciousness and Communicative Action, Christian Lenhardt \& Shierry Weber Nicholsen (trans.) (Cambridge, MA: MIT Press, 1991), p. 133. For more details see Habermas, op. cit., supra note 14, pp. 279289.
} 
binding/bonding effect (BindungsEffekt) of the offer contained in his speech act."33 Therefore, the significance of communicative action lies in its 'binding effects' among social actors not through violence, manipulation and domination, but through unconstrained public discussion. ${ }^{34}$ Habermas, first and foremost, concentrates on the contrast between strategic action and communicative action since they rely on the coordination of action plans of at least two participants. In his view, the possible choice between communicative and strategic action exists only in an abstract sense, i.e. individual case, since "the individuals acquire and sustain their identity by appropriating traditions, belonging to social groups, and taking part in socializing interactions." 35 Therefore, the long-term absence from contexts of 'action-oriented to reaching agreement' is not an option for individuals.

In a nutshell, Habermas criticizes neither the uncoupling of system and lifeworld as a result of rationalization process nor coordination of the subsystems of 'the lifeworld' by money and power. What he is critical about is the obstruction of the potential of modern societies to reach 'communicative freedom' by the one-sided rationalization of modernity. He conceptualizes this obstruction in terms of the system's 'colonization of the lifeworld' and the 'impoverishment of culture.' In the next section, I will delineate these processes in relation to their implications on the phenomena of 'the political.'

\footnotetext{
${ }^{33}$ Jürgen Habermas, "Discourse Ethics: Notes on a Program of Philosophical Justification," Moral Consciousness and Communicative Action, Christian Lenhardt \& Shierry Weber Nicholsen (trans.) (Cambridge, MA: MIT Press, 1991), p. 58.

${ }^{34}$ Habermas, op. cit., supra note 14, p. 285.

${ }^{35}$ Habermas, op. cit., supra note 33, p. 102.
} 


\subsection{The Cost of Modernity: 'Colonization of the Lifeworld'}

According to Habermas, the pathologies of modernity can be understood only by using the conceptual framework of communicative action in which the contradictions of the process of societal rationalization become clear at the outset. He sees the contradiction between the rationalization of everyday communication in which language is identified as a "genuine and irreplaceable medium of reaching understanding" and the increasing complexity of subsystems "in which actions are coordinated through the steering media such as money and power." ${ }^{36}$ In this sense, the pathologies of modernity arise from the intrusion into the rationalized communication of everyday life by "unleashed functionalist reason of system maintenance." ${ }^{37}$ In other words, a 'colonization of the lifeworld' occurs when the domain of consensus-dependent actions become subject to the autonomous, formally organized imperatives of systemic mechanisms. At this point, Habermas insistently emphasizes that "competition takes place not between the types of action oriented to understanding and to success, but between the principles of societal integration." 38 To elucidate, the contradiction is defined as being between "the linguistic communication that is oriented to validity claims" and "those de-linguistified steering media through which systems of success oriented to action are differentiated out." ${ }^{, 39}$ It is my contention that this reveals a shift in Habermas' thought from the 'philosophy of consciousness' to the 'paradigm of language.' Instead of expressing the implications of an increasing application of 'instrumental

\footnotetext{
${ }^{36}$ Habermas, op. cit., supra note 14, p. 342.

${ }^{37}$ Habermas, op. cit., supra note 18, p. 399.

${ }^{38}$ Habermas, op. cit., supra note 14, p. 342.

${ }^{39}$ Ibid., p. 342.
} 
rationality,' which differentiates him from the Frankfurt tradition of critical theory, he points out the 'reification of communication' through the invasion of delinguistified, norm-free imperatives of system mechanism in the domain of communicative action.

The reason for this intervention is to avoid the critical imbalances in material reproduction, that is, the 'steering impasses.' However, the ways in which this disequilibrium is abstained engenders disturbances in symbolic reproduction of 'the lifeworld' since the expansion of the systemic integration undermines functions of communicative action. In other words, the systemic media of money and power displaces 'communicative sociation' as a principle of social integration in core spheres of action, i.e. culture, society, and personality. But, by which means can this happen if the system mechanisms disengaged from 'the lifeworld'? To address this question, Habermas draws attention on 'public' and 'private' spheres through which economic and state systems remain related to and embedded in 'the lifeworld.' In Habermas' view, the disengagement of system from 'the lifeworld' is accompanied with the differentiation of 'the lifeworld' into two spheres whereby economic and administrative systems are situated in the context of everyday norms and mekningsultial to point out that Habermas offers an essential corrective to the 'dualistic' understanding of public and private separation in liberal democratic theory. Contrary to such a presupposed strict separation of the public from the private, he reconceptualizes this separation in terms of family, economy, state, and

\footnotetext{
${ }^{40}$ Habermas decisively emphasizes that "[i]t is these media [money and power], and not directly the purposive-rational action orientations themselves, that need to be institutionally and motivationally anchored in the lifeworld." Habermas, op. cit., supra note 14, p. 342.
} 
public sphere, and the multiple relations among them. ${ }^{41}$ In this sense, the "public sphere' or the space of political participation, debate and opinion is related to the administrative system, while the 'private sphere' which is identified with modern nuclear family is related to economic system. The exchanges between the public sphere and administrative system are channeled through the roles of 'citizen' and 'client,' whereas the exchange between the private sphere and economy are channeled through the roles of the 'worker' and the 'consumer. ${ }^{42}$ The compensation for the control exercised over individuals as workers and citizens "comes in the form of system-conforming rewards which are channeled into the roles of private consumer and public client of the welfare state."43

This compensation indicates the role of law as a 'steering medium' that connects economic and administrative systems to 'the lifeworld.' But, Habermas claims, the 'law as a medium' remains bound up with the 'law as an institution' in which the legitimacy of norms is questioned. Law regulates "legitimacy of the legal order and the moral-practical foundations of the domains of action" since the emergence of the bourgeois state. ${ }^{44}$ However, in the social and democratic constitutional state, the balance between 'law as a medium' and 'law as an institution' is shifted towards to the former that is identified with action oriented toward 'formal law.' Habermas considers this process as a specific kind of

\footnotetext{
${ }^{41}$ For Habermas' analysis of the rise and fall of bourgeois public sphere see Jürgen Habermas, The Structural Transformation of the Public Sphere, T. Burger (trans.) (Cambridge, Polity Press, 1989).

${ }^{42}$ Habermas, op. cit., supra note 18, pp. 348-351. For more details see Fraser, op. cit., supra note 30, pp. 112-113.

${ }^{43}$ Stephen K. White, The Recent Work of Jürgen Habermas (Cambridge: Cambridge University Press, 1988), p. 112.

${ }^{44}$ Habermas, op. cit., supra note 14, p. 342.
} 
'juridification.' 45 This juridification process, which expands the 'freedomguaranteeing' line of juridification to economic action-system, generates a new type of dependency between the 'client' and the 'administration,' and in turn, entails the redefinition of everyday life situations; for instance, family relations, education, mental and physical health, and old age. Such redefinition of everyday situations necessitates objectification and violent abstractions not only to render everyday life situations subsumable under legal categories, but also to make it possible for them to be handled administratively. It is my contention that these attempts to objectify action situations and abstract individuals from their particular context and their embodiment disregards particularity and plurality in favor of universality and uniformity in the public sphere. In my view, this interpretation and application of law directly reflects an influence of scientific method on social sciences.

More succinctly, the bureaucratization and monetarization of the core areas of life by a medium of law generates a shift from social to system integration within the rationalization process of 'the lifeworld.' The public sphere is transformed since the distinction between public and private becomes blurred. Thus, a 'self-critical perspective' and a 'public use of reason,' which flourishes from communicative action, are replaced by power relations taking place between private bureaucracies, special interest associations, and public administration. In this regard, Habermas argues that "the notion of an objective general interest [is] replaced, even ideally,

\footnotetext{
${ }^{45}$ Habermas distinguishes four epochal juridification processes, i.e. the bourgeois state, the bourgeois constitutional state, the democratic constitutional state, and the social and democratic constitutional state. For more details see Jürgen Habermas, "Law as Medium and Law as Institution," in Dilemmas of Law in the Welfare State, G. Teubner (ed.) (New York: de Gruyter, 1986). For more details see also Habermas, op. cit., supra note 18, pp. 356-373.
} 
with one of a fairly negotiated compromise among interests." ${ }^{46}$ Meanwhile, economic society and family are polarized through the establishment of a 'world of work' as its own right and therefore the private sphere and the intimate sphere are equalized.

This juridification process coincides with 'commodification' as a complementary process in the private sphere. The role of 'worker,' which sheds light on a contradiction between discourse and reality, is substituted by the role of 'consumer,' which directs attention to varieties of goods and services provided by an economic subsystem and, in turn, areas of private life such as leisure activities, sexual relations, family relations, and personal development are increasingly shaped by commodity economy and mass consumption. ${ }^{47}$ Therefore, the 'colonization of the lifeworld' engenders an increasing detachment of individuals from the action coordination mechanism based on the "communicatively achieved consensus." As a result, individuals not only become alien to system in which they live, but also they lose their control over their everyday practices which is regulated by the modern 'Leviathlam.ermas' reinterpretation of Weber's 'loss of freedom' in terms of the 'colonization of the lifeworld' continues with his reinterpretation of Weber's 'loss of meaning' by reference to the process of 'cultural impoverishment.' In contrast to Weber, Habermas argues that it is not the differentiation and independent development of cultural value spheres that leads to the cultural impoverishment of everyday communicative practice, but elitist splitting off of expert cultures from the context of communicative action in daily life. In other words, the connection

${ }^{46}$ Craig Calhoun, "Introduction: Habermas and the Public Sphere," in Habermas and the Public Sphere, Craig Calhoun (ed.) (Cambridge, Mass: MIT Press, 1992), p. 22.

${ }^{47}$ White, op. cit., supra note 43, pp. 112-115. 
between system mechanisms and the understanding of the majority of people is lost because the ground of the argumentation process becomes defined only by reference to the scientific knowledge of insulated experts. Consequently, even though an advanced capitalist society provides great quantities of information to its citizens, either they have no motivation to be interested in the knowledge because of their disposition in the public sphere as clients or the knowledge is rendered alien to them. This situation makes it harder for their everyday consciousness to synthesize and to criticize information in order to produce a coherent interpretation of the world. In keeping with this line of argument, Habermas argues that

[i]n the place of false consciousness there appears today fragmented consciousness, which hinders enlightenment about the mechanism of reification. The conditions for a colonization of the lifeworld are thereby fulfilled: as soon as it is stripped of its ideological veil, the imperatives of independent subsystems press in from the outside on the lifeworld and compel assimilation, like colonial masters in a tribal society. [And] the perspectives of the native culture are so scattered that they cannot be coordinated sufficiently to allow the workings of the metropole and world market to be deciphered from a peripheral standpoint. ${ }^{48}$ (Emphases are original).

In this vein, it can be asserted that the most significant influence of the 'colonization of the lifeworld' and of 'cultural impoverishment' is to cover the perils of disequilibrium which occurs in the political and economic systems as a result of the withdrawal of legitimation and motivation in order to prevent the emergence of critical consciousness and the formation of alternative movements. In other words, the pathologies of modern society such as alienation, insecurity of collective identity and cultural impoverishment hinder the emergence of critical thought as a basis of questioning the given reality. This point is important in understanding the shift in

${ }^{48}$ Ibid., p. 355. 
Habermas' analysis from Legitimation Crisis to the Theory of Communicative Action. In Legitimation Crisis, Habermas illuminates the results of growing intervention of the state into the economy by reference to legitimation and motivation crises. This intervention, according to him, has the effect of repoliticizing areas of social life because a contrast between class structure and universalistic and democratic values becomes more apparent. However, in Theory of Communicative Action, Habermas accords more resilience to a capitalist society. While he sees the crises of legitimation and motivation as imperatives of 'repoliticization' in Legitimation Crisis, he views the pathologies of 'the lifeworld' as veils of the reification mechanism that prevents the emergence of critical and reflective consciousness in Theory of Communicative Action. To put it somehow differently, the 'reification of communication' and the 'fragmentation of consciousness' are elucidated by reference to their functionality in the social and democratic constitutional state since the necessity of relying on a normatively secured and communicatively achieved agreement is decreased. ${ }^{49}$

To conclude, the withdrawal of both legitimation and motivation generates the 'colonization of the lifeworld' by the system mechanisms and the 'cultural impoverishment' of society. As a result, communicative rationality, which springs up from the rationalization of 'the lifeworld,' is rendered almost invisible by a smoke screen of the pathologies of modern society. Modern individual, who flutters to find a secure place for herself or himself in a world where everything is melting into air, recedes into a secluded sphere of the intimate. In doing so, the public sphere, which was seen as a sphere in which human beings can reach the good life in Ancient times, is left with a rigid instrumentality of system. Thus, the power of ${ }^{49}$ Ibid., pp. 343-373. 
individuals to determine under which rules they want to live is reduced to a dehumanized and de-linguistified network of the system mechanisms and 'the truth' of the techne-crafts.

Habermas suggests the protection and expansion of the sphere of communicative action is needed against the systemic imperatives of the economy and the state to address and resolve the distortions and pathologies of modernity. In this sense, he establishes the public sphere with this goal in mind and, in turn, develops 'moral politics' on the basis of a principal relation between morality, law and politics. In the light of these arguments, I want to carry forward my discussion to Habermas' 'moral politics' as an alternative to the liberal conception of 'the political' with two basic questions: What does his 'moral politics' offer for a new conceptualization of 'the political'? How does he identify the concept of 'the political' in relation to morality, ethics and law? 


\section{Chapter 2}

\section{Habermas' Reconceptualization of 'the Political': Procedural Restatement of Liberal 'Rule of Law'}

"For morality is a device woven with the threads of communication to shield the peculiar vulnerability of socialized individuals."

Jürgen Habermas

From his earliest writing on the rise and fall of the public sphere to his most recent writings on the relation between politics, law and morality in Between Facts and Norms, the nature and limits of liberal democracy have remained as a central theme for Jürgen Habermas' political theory. His democracy project finds its roots in Rousseauian and Marxian versions of democracy which has been expressed in the vision of 'rational collective identity.' However, he is skeptical of the holistic conceptions of democracy in which society is seen as "a kind of macro-subject integrated via a central agency (the state) or organizing principle (labor)." For Habermas, in highly differentiated and pluralist modern societies, democracy cannot be defined with reference to the substantive values and traditions of a homogenous political community. By his challenge, he wants to show that the primary subject and object of democratization can no longer be seen as a society but rather "the association of free and equal consociates under law (Rechsgenossen)." In this sense, he develops the counterintuitive concept of 'subjectless communication,' which preserves the core idea of radical democracy claiming that

\footnotetext{
${ }^{1}$ Kenneth Baynes, "Democracy and the Rechsstaat: Habermas' Faktizität und Geltung," in The Cambridge Companion to Habermas, Stephen K. White (ed.) (Cambridge: Cambridge University Press, 1995), p. 201.
} 
citizens are the authors of legitimate laws to which they are subjected without resort to a general will. $^{2}$

Habermas' deliberative account of democracy necessitates a strongly normative account of legitimacy in arguing that the validity claims of citizens must be tested and justified in terms of reasons that "all could accept" in public debates. In his attempt, Habermas locates the notion of justice at the center of his theory of democracy, while the concept of freedom as self-determination is placed at the center of his understanding of 'the political.' Therefore, Habermas' discourse ethics is a theory of 'political morality,' while his political theory is a 'moral politics' which privileges universal law over the conflicts of interests and struggles for recognition. ${ }^{3}$ At this point, it can be claimed that his understanding of 'the political' is grounded in the theory of discourse ethics that suggests procedural guidelines for discourse by setting out what is entailed and presupposed as structural necessities by the idea of "being convinced by reason." Cronin argues that such an understanding is limited in the sense that it is defected by "the abstractness of the modern autonomous subject and the inevitable emptiness of formal principles grounded solely in the constraints of an unsituated reason."4

In the first section, I will explain Habermas' discourse ethics in order to clarify 'why' and 'how' it becomes the reference point to determine the structural necessities of discourse and also the use of 'public reason.' Further, I will examine Habermas'

\footnotetext{
${ }^{2}$ William Rehg \& James Bohman, "Discourse and Democracy: The Formal and Informal Bases of Legitimacy in Between Facts and Norms," in Discourse and Democracy: Essays on Habermas's Between Facts and Norms, René Von Schomberg and Kenneth Baynes (eds.) (Albany: State University of New York, 2002), p. 31.

${ }^{3}$ Thomas McCarthy, "Practical Discourse: On the Relation of Morality to Politics," in Ideals and Illusions: On Reconstruction and Deconstruction in Contemporary Critical Theory (Cambridge: The MIT Press, 1991), p. 181.

${ }^{4}$ Ciaran Cronin, "Introduction," in Justification and Application: Remarks on Discourse Ethics, Ciaran Cronin (trans.) (Cambridge: MIT Press, 1993), p. xxi.
} 
justification of discourse ethics as a basis for his deliberative politics. In the second section, I will demonstrate the relation between politics, law, and morality in relation to Habermas' effort to reconcile subjective and objective rights, and private and public autonomy. This section will be followed by the employment of practical reason in order to clarify what kind of questions and aspects are involved in discourse ethics. On the basis of these arguments, Habermas' concept of deliberative politics will be presented in the fourth section, while a critical perspective will be developed on his conceptualization of 'the political' in the final section.

\subsection{Theory of Discourse Ethics: 'Moral Politics'}

Habermas' discourse ethics can be seen as one of the most original cognitivist and deontological moral theories in contemporary moral philosophy. His goal is to articulate Kantian abstract universalism with the relativistic and contextualist communitarianism, which follows the Aristotelian and Hegelian traditions. Following Kant, he distinguishes the types of practical reasoning in the name of appropriate questions about "what is practically expedient, ethically prudent, and morally right." ${ }^{, 5}$ Like Kant, he identifies the question of "what the right is" from a moral point of view, rather than posing ethical questions of "who one is" and "who one wants to be." He claims that as a result of disenchantment of the world, metaphysical and religious worldviews have lost their capacity to justify the norms of social interaction. In turn, the question of "how should we live?" turns into the question of "how should we regulate our interactions?" as autonomous individuals in a pluralist modern society. On the basis of this argument, he

5 Thomas McCarthy, "Legitimacy and Diversity: Dialectical Reflections on Analytical Distinctions," in Habermas on Law and Democracy: Critical Exchange, Michael Rosenfeld and Andrew Arato (eds.) (Berkeley: University of California Press, 1998), p. 121. 
reconceptualizes the notion of autonomy and practical reason with the goal of justifying the cognitivist and universalist claims of Kant's moral theory within a dialogical framework.

His reinterpretation of the notion of 'autonomy' and 'practical reason' is derived from his theory of communicative action in the sense that communicative action becomes the only basis of the social integration in modern society as a consequence of the secularization and rationalization processes. To put it differently, communicative action as an 'action oriented toward reaching an understanding' on the basis of criticizable validity claims becomes essential to social order since it provides a valid basis of social integration through argumentation processes. Habermas identifies three types of validity claims in speech acts: claims to truth, claims to rightness, and claims to truthfulness. Those claims are deemed to be universal, and corresponded to different attitudes, worlds, and areas of modern societies. Claims to truth by which a speaker refers to something in the objective world have an objectivating attitude, and are associated with the area of science in modern society, while claims to rightness by which a speaker refers to something in the social world have a norm-confirmative attitude, and are associated with law and morality in modern life. Finally, claims to truthfulness have an expressive attitude through which the speaker refers to something in her or his own subjective world, and are associated with aesthetic and ethics in modern society. ${ }^{6}$

The fact that a speaker can rationally motivate a hearer to accept such an offer is due not to the validity of what he says but to the speaker's guarantee that he will, if necessary, make efforts to

\footnotetext{
${ }^{6}$ Jürgen Habermas, "Moral Consciousness and Communicative Action," in Moral Consciousness and Communicative Action, Christian Lenhardt \& Shierry Weber Nicholsen (trans.) (Cambridge: MIT Press, 1991) (seventh edition), pp. 136-138; James Tully, 'To Think and Act Differently: Foucault's Four Reciprocal Objection to Habermas' Theory,' in Foucault Contra Habermas, Samantha Ashenden and David Owen (eds.) (London: SAGE Publication, 1999), p. 101.
} 
redeem the claim that the hearer has accepted. It is this guarantee that effects the coordination between speaker and hearer. In the case of the claims to truth or rightness, the speaker can redeem his guarantee discursively, that is, by adducing reasons; in the case of the claims to truthfulness he does so through consistent behavior (Emphasis added). ${ }^{7}$

In other words, the validity of communicative action depends on the persuasion of hearer to accept a speech-act offer by the speaker's guarantee to redeem a criticizable validity claim, if it is necessary. It is this guarantee that creates the binding and bonding effects between 'hearer' and 'speaker,' and provides the maintenance of their interaction. ${ }^{8}$ At this point, Habermas argues that validity claims to truth and rightness can be redeemed discursively, while claims to truthfulness can be redeemed only by consistent action. The essential point here is his treatment of claims to normative rightness like truth claims in the name of objectivity. The redemption of claims to propositional truth and normative rightness discursively means that participants who raise such validity claims in communicative action are able to give 'good reasons' for their claims. The criteria of 'good reasons' for truth claims referring to an objective world are judged by reference to the principle of induction in the discourse of empirical sciences. In relation to his discourse ethics, Habermas' main goal is to provide a moral principle as a rule of argumentation which functions equivalently to the principle of induction. ${ }^{9}$ However, the

\footnotetext{
7 Jürgen Habermas, "Discourse Ethics: Notes on a Program of Philosophical Justification," in Moral Consciousness and Communicative Action, Christian Lenhardt \& Shierry Weber Nicholsen (trans.) (Cambridge: MIT Press, 1991) (seventh edition), pp. 58-59.

${ }^{8}$ Ibid., p. 59.

${ }^{9}$ Habermas sees claims to propositional truth and normative rightness as coordinators of action, and he indicates that they play their roles in different ways within communicative practices of everyday life. He finds an intrinsic connection between language and the social world, whereas he cannot find the same relation between language and the objective world. More specifically, since he claims, the social order cannot be formed independent from validity, there is an expectation about the possible justifiability of existing norms. He asserts that this is why we look at logic of
} 
redemption of validity claims necessitates the elimination of power asymmetries and any type of coercion from communication. For this reason, he describes the 'ideal speech situation' in which every subject has an unrestricted right to participate and communication is free from all forms of coercion. ${ }^{10} \mathrm{He}$ presupposes the characteristics of the 'ideal speech situation'-reciprocal recognition and communicative freedom-as the basis of the discursive redemption of claims to truth and rightness.

\subsubsection{The Principle of Moral Argumentation}

From this account of communication, Habermas turns his attention to developing a moral principle as a rule of argumentation which makes valid moral judgments possible. In Tully's words, he focuses on the question "what is given to us as a limit universal, necessary, and obligatory-that cannot be otherwise?"11 In the light of this question, Habermas introduces the principle of universalizability $(U)$ as a rule of moral argumentation that is seen parallel with the principle of induction in the discourses of the empirical sciences with reference to its function. ${ }^{12}$ He claims that "[f]or a norm to be valid, the consequences and side-effects of its general observances for the satisfaction of each person's particular interests must be freely accepted by all." ${ }^{, 13}$ In other words, each participant in practical argumentation should adopt the perspectives of all others who are affected by the consequences and side-effects of the proposed norm. The idea of the

practical reason when we want to learn "what makes valid moral judgments possible." However, claims to truth have no intrinsic relation with entities in an objective world unlike claims to rightness because "states of affairs, for their part, must be assumed to exist independently whether we formulate them by means of true propositions or not." Ibid., pp. 59-63.

${ }^{10}$ Cronin, op. cit., supra note 4, p. xv.

${ }^{11}$ Tully, op. cit., supra note 6, p. 100.

${ }^{12}$ Habermas, op. cit., supra note 6, p. 63.

${ }^{13}$ Jürgen Habermas, "Morality and Ethical Life: Does Hegel's Critique of Kant Apply to Discourse Ethics?" Northwestern University Law Review 83 (1989), p. 40. 
adoption of the perspectives of all others is derived from G. H. Mead's concept of "idealrole taking" in order to reach consensus on generalizable interests. ${ }^{14}$

The conceptualization of the principle of universalizability finds its roots in the Kantian categorical imperative which constitutes a test that can be applied by each individual as if a proposed norm can become a universal norm or not. ${ }^{15}$ However, this monological Kantian categorical imperative is replaced by a dialogical one in Habermas' discourse ethics in conjunction with his transition from a philosophy of consciousness to a philosophy of language. McCarthy explains Habermas' reformulation of categorical imperative as follows:

Rather than ascribing as valid to all others any maxim that I can will to be universal law, I must submit my maxim to all others for purposes of discursively testing its claim to universality. The emphasis shifts from what each can will without contradiction to be a general law, to what all can will in agreement to be a universal norm. ${ }^{16}$

In Moral Consciousness and Communicative Action, the principle of universalizability is followed by an introduction to a principle of discourse (D), which "presupposes that we can justify our choice of a norm."17

\footnotetext{
${ }^{14}$ Habermas, op. cit., supra note 6, p. 65.

${ }^{15}$ Immanuel Kant, Fundamental Principles of the Metaphysics of Morals, T. K. Abbott (trans.) (New York: Prometheus Books, 1988), pp. 33-77.

${ }^{16}$ Thomas McCarthy, The Critical Theory of Jürgen Habermas (Cambridge \& Massachusetts \& London: The MIT Press, 1978), p. 326. It is worth noting here that Habermas reformulates Kant's categorical imperative not only in terms of dialogical argumentation but also by his addition of interests and consequences, which are not included by Kant, to the principle of universalizability. For more details see Tully, op. cit., supra note 6, p. 104.

${ }^{17}$ In Moral Consciousness and Communicative Action, the principle of universalizability can be seen as a kind of master principle from which other principles, such as the principle of discourse, are derived. However, in Between Facts and Norms, Habermas delineates the difference between these two principles more sharply in order to clarify the importance of this difference in the name of overcoming the subordination of law to morality or vice versa. I will return to this point in following chapters. For more details see Jürgen Habermas, Between Facts and Norms: Contribution to a Discourse Theory of Law and Democracy, William Regh (trans.) (Cambridge:
} 
From Habermas' standpoint, the principle of universalizability is a procedural principle of practical argumentation that can be seen as a reinterpretation of the 'formal' character of Kant's categorical imperative. Similar to the categorical imperative it does not directly describe any particular normative principles, but it provides the condition such principles must meet in order to be justified. In other words, the principle of (U) does not tell us "what justice demands" with reference to determinate norms that guide actions; but rather, it clarifies "what justice is" in the sense of providing universally valid criteria that guarantee the impartiality of moral judgments. ${ }^{18}$ In doing so, like Kant, Habermas secures the autonomy of individuals by rejecting all sources of moral authority which are external to the wills of moral agents. In relation to its proceduralist character, the principle of $(U)$ can be seen as 'universalistic' because it does not reflect any particular culture or epoch, but only an abstract rule of moral argumentation. This abstract character of the principle of (U) leads us to ask: where does Habermas derive the principle of universalization? In the next section, I will try to explain the philosophical basis of the 'rule of moral argumentation.'

\subsubsection{The Philosophical Justification of the Principle of Universalizability}

Habermas' philosophical justification for discourse ethics is grounded on 'transcendental-pragmatic' arguments, specifically the arguments of Karl-Otto Apel. The goal of Habermas in using transcendental-pragmatic arguments is to demonstrate how the 'principle of universalization' is implied by the presuppositions of argumentation in

Polity Press, 1996), pp. 450-457. Mitchell Dean, "Normalising Democracy: Foucault and Habermas on Democracy, Liberalism and Law," in Foucault Contra Habermas, Samantha Ashenden and David Owen (eds.) (London: SAGE Publication, 1999), pp. 179-180.

${ }^{18}$ Stephen K. White, The Recent Work of Jürgen Habermas (Cambridge: Cambridge University Press, 1988), p. 50. 
general. ${ }^{19}$ In Remarks on Discourse Ethics, Habermas says "[t]ranscendental-pragmatic arguments are designed to remind anyone who so much as enters into argumentation that he is already participating in a normatively structured practice." 20 In other words, transcendental-pragmatic arguments are constructed on the unavoidability and indisputability of practices and experiences from which people cannot separate themselves. Habermas argues that the unavoidable features of practices and experiences are hidden in communicative action in the sense that human beings are social beings. To put it differently, human beings are dependent on practical interaction in order to preserve and reproduce their identities. Therefore, "we are already implicitly committed to the normative presupposition of argumentative discourse."21

At this point, it should be noted that Habermas sees discourse as a continuation of communicative action by other means. Argumentation is viewed as a reflexive form of communicative action, which emerges when unquestioned features of the lifeworld are thematized and become problematic. In this sense, "[it] derives the pragmatic presuppositions we found at the procedural level from the presupposition of communicative action." $22 \mathrm{He}$ differentiates the presuppositions of argumentation as conventional and post-conventional ones. Conventional presuppositions include logicalsemantic rules of consistency, mutual recognition, and reciprocity. ${ }^{23}$ However, Habermas finds conventional presuppositions limited in the sense of grounding a relevance of

\footnotetext{
${ }^{19}$ Habermas, op. cit., supra note 6, pp. 86.

${ }^{20}$ Jürgen Habermas, "Remarks on Discourse Ethics," in Justification and Application: Remarks on Discourse Ethics (Cambridge, MA: MIT Press, 1993), p. 77.

${ }^{21}$ Cronin, op. cit., supra note 4, p. xvii.

${ }^{22}$ Habermas, op. cit., supra note 7, p. 100.

${ }^{23}$ Like aforementioned, "the structures of action oriented toward reaching understanding always already presuppose those very relationships of reciprocity and mutual recognition around which all moral ideas revolve in everyday life." ${ }^{, 23}$ Habermas, op. cit., supra note 6, p. 130. For more details see Habermas, op. cit., supra note 7, pp. 86-89, and 100-102.
} 
argument on conventional consensus. As a result, Habermas adopts $\mathbf{R}$. Alexy's rules of discourse as the post-conventional presuppositions of argumentation, which inescapably has normative content:

(1) Every subject with the competence to speak and act is allowed to take part in a discourse.

(2) a. Everyone is allowed to question any assertion whatever. b. Everyone is allowed to introduce any assertion whatever into the discourse.

c. Everyone is allowed to express his attitudes, desires, and needs.

(3) No speaker may be prevented, by internal or external coercion, from exercising his rights as laid down in (1) and $(2) .^{24}$

These post-conventional presuppositions of discourse- the principle of universal moral respect, the principle of egalitarian reciprocity, and the principle of non-coerciontranscend the borders of the conventional consensus by opening all validity claims to critical argumentation of all affected. ${ }^{25}$ With his distinction between communicative action and discourse, Habermas makes "a fairly clear distinction between relatively unreflective everyday thought and the reflective activity of questioning a limit (practical discourse)." ${ }^{\text {26 }}$ However, "a form of subjectivity is not a limit from outside of the experiences of the subjects themselves; it is the limit of their experiences as thinking subjects from the inside ${ }^{, 27}$ in the name of the forms of knowledge, relations of power, and practices of the self. In this respect, it can be claimed that the reflective thought cannot be restricted to the experiences of the juridical subject. In contrast, it has its roots

\footnotetext{
${ }^{24}$ Habermas, op. cit., supra note 7, p. 89.

${ }^{25}$ Tully, op. cit., supra note 6, pp. 103-107.

${ }^{26}$ Ibid., p. 97.

${ }^{27}$ Ibid., p. 97.
} 
in every manner of the individual's doings or acts as a subject of learning, as both an ethical and a juridical subject, "as subject conscious of himself and others.",28

In order to clarify the function of the rules of discourse, Habermas makes an analogy between the presuppositions of practical argumentation and a chess game:

Rules of discourse in Alexy's sense are not constitutive of discourses in the sense in which chess rules are constitutive of real chess game. Whereas chess rules determine the playing of actual chess games, discourse rules are merely the form in which we present the implicitly adopted and intuitively known pragmatic presuppositions of a special type of speech, presuppositions that are adopted implicitly and known intuitively (Emphases in original). $^{29}$

The essential points here are the description of discourse rules as a form, rather than substantive principles, and the implicit adoption and the intuitive knowledge of the presuppositions of practical argumentation. To put it differently, discourse ethics establishes a procedure that is based on presuppositions and is designed to secure the impartiality of the process of judging. Habermas associates the discursive procedure with Kohlberg's postulation for moral judgments at the post-conventional level: reversibility, universality, and reciprocity. ${ }^{30}$ In parallel to Kohlberg, Habermas perceives the transition from one stage to another as a learning process. Moreover, this learning process is seen as a constructive achievement on the part of the learner. In this regard, Habermas links discourse ethics with constructivist notion of learning in the sense that it is a reflective form of communicative action and it postulates a change of attitude for the transition

\footnotetext{
${ }^{28}$ Ibid., p. 97.

${ }^{29}$ Habermas, op. cit., supra note 6, p. 91.

${ }^{30}$ In order to support the idea of universality of discourse ethics, Habermas turns to the insights of cognitive developmental psychology. He specially uses Lawrence Kohlberg's theory on the development of moral judgment. Kohlberg differentiates six stages of moral judgment each of which reflects a new and more adequate set of cognitive operations for individual's capacity for moral judgment. Ibid., pp. 119-133.
} 
from action to discourse. This attitude change indicates "(U) and (D) as characteristic of moral judgment that can serve as normative points of reference in describing the development of the capacity for moral judgment." ${ }^{\text {,31 }}$ It should be noted here that by adopting Kohlberg's stages into his theory of communicative action, he clarifies the development of moral consciousness with reference to interaction. In doing so, he shows that reciprocity appears in different stages of interaction, which proves that reciprocity is 'the naturalistic kernel of moral consciousness.' That is to say, "the point of view of reciprocity belongs eo ipso to the interactive knowledge of speaking and acting subjects," and thus, it cannot be tied to any particular culture, but rather it is universal. In this way Habermas clarifies the implicit adoption and intuitive knowledge of presuppositions which can always provide a potential consensual standard for conflict resolution. In doing so, he views the principles of discourse as "universal pragmatic presuppositions" of speech acts "corresponding to the know-how of 'moral' agents at the post-conventional level." ${ }^{32}$ However, McCarthy criticizes Habermas for neglecting the charges of ethnocentrism and of scientific and rationalist bias of cognitive-developmental paradigms in general. In turn, Habermas assumes a univocal description of the "know-how" of moral actors at the post-conventional stage of moral reasoning even though there cannot be any univocal description for this stage. ${ }^{33}$

Habermas uses Karl-Otto Apel's concept of 'performative contradiction' to explain the position of people who are to reject the presuppositions of communicative

\footnotetext{
${ }^{31}$ Ibid., pp. 122-123.

${ }^{32}$ Seyla Benhabib, "In the Shadow of Aristotle and Hegel," in Situating The Self: Gender, Community, and Postmodernism in Contemporary Ethics (Cambridge: Polity Press, 1992), p. 30.

${ }^{33}$ Ibid., p. 30. For more details see Thomas McCarthy, "Reason and Rationalization: Habermas 'Overcoming' of Hermeneutics," in Ideals and Illusions: On Reconstruction and Deconstruction in Contemporary Critical Theory (Cambridge: The MIT Press, 1991), pp. 127-152.
} 
action. Since the validity of these presuppositions can only be questioned or tested through argumentation, people who were to reject the normative validity of these norms would have to engage in argumentation processes that implicitly support the principle of universalization itself. By engaging in argumentation, they unavoidably make some presuppositions necessitated by the logic of the argumentation concerned. But, these presuppositions contradict what they defend, and thereby they inevitably fall into a "performative contradiction." 34

By his justification of the principle of universalizability as an implicit and intuitive principle in moral argumentation itself, Habermas does not leave an open door for alternatives. In other words, by unavoidability and indisputability of the principle of universalization as a 'fact of reason,' "no one has the option of escaping to alternatives. ${ }^{, 35}$ Even though he gives skeptics a chance to be critical about the rule of argumentation or the presuppositions of practical argumentation, he accuses them falling into performative contradiction. In this regard, to have the chance to be critical about the rule of argumentation can only be a tautology. It is my contention that his justification of discourse ethics and his notion of 'performative contradiction' indicate one of the limitations of his understanding of politics in the sense of its restrictions on the possible challenges to the procedures of discursive opinion- and will-formation and transgression of the limits set by it.

Moreover, it should be noted that these unavoidable pragmatic presuppositions of speech form the normative content of communicative democracy. This strategy is

\footnotetext{
${ }^{34}$ Habermas, op. cit., supra note 7, p. 85.

${ }^{35}$ Habermas, op. cit., supra note 6, p. 130.
} 
forcefully criticized by Castoriadis as mere reduction of jus to factum, of 'ought' to 'is. ${ }^{36}$ Castoriadis describes this reduction as 'biological positivism' in the sense that it carves the notion of freedom in participants' genes. ${ }^{37}$ For the sake of avoiding substantive principles, Habermas reduces 'ought' to 'is,' like Lawrence Kohlberg. As a result, he does not feel a need to question whether discursive procedures are sufficient to generate a rational public opinion or not.

From this account, I want to discuss the relation between Habermas' theory of discourse ethics and his notion of deliberative politics. Since Habermas' notion of deliberative politics is closely linked to his theory of law, I will start with the relation between political power and law with reference to the idea of government by law (Rechtsstaat). I will explain this idea in terms of the conditions that must be satisfied for the generation of communicative power, and the reconciliation of subjective and objective rights.

\subsection{The Internal Relation between Law and Politics}

In the wake of secularization and rationalization, metaphysical and religious worldviews have lost their power to create consensus and stability with reference to the unquestionable overpowering authority of strong institutions and shared backgrounds. This loss of the 'sacred canopy' has led to the split between facticity-a social realityand validity - a claim of reason - while they were fused together through which they have kept certain issues and assumptions from challenge. The social reproduction and

\footnotetext{
${ }^{36}$ Cornelius Castoriadis, "Democracy as Procedure and Democracy as Regime," in Constellations 4 (1) (1997), pp. 7-12. See also Andreas Kalyvas, "The Politics of Autonomy and the Challenge of Deliberation: Castoriadis contra Habermas," Thesis Eleven 64 (February 2001), p. 5.

${ }^{37}$ Ibid., p. 5. The same critique is brought up by Seyla Benhabib in the name of Lawrence Kohlberg's theory on moral judgment. For more details see Benhabib, op. cit., supra note 32, p. 30 .
} 
integration therefore had to look elsewhere to fulfill the tasks of social coordination and integration. According to Habermas, communicative action oriented to reaching understanding has appeared as a means of cultural reproduction, social integration and solidarity, and socialization at the lifeworld level, while non-linguistic strategic action turned out to be a necessity in the functionally differentiated system level. However, the fragmentation of shared identities and the erosion of substantive lifeworld resources for consensus by societal pluralization on the one hand, and the differentiation of spheres of validity and the differentiation of functional spheres of material reproduction in which individuals are left free to pursue their own ends under the dictatorship of purposive rationality on the other hand, have created the problem of social coordination. In turn, the question is raised: what could be a means of agreement in highly differentiated and pluralistic societies? Habermas responds to this question by introducing 'modern law' which is presented as a 'system of rights' in terms of its specific function of stabilizing behavioral expectations. ${ }^{38}$ However, "[t]hese rights can take effect and be enforced only by organizations that make collectively binding decisions." ${ }^{\text {39 }}$ Therefore, it can be said that while law presupposes a political power, political power can develop only through a legal code. Habermas claims,

In the dimension of legal validity, facticity and validity interlock ones more, but this time the two moments do not bond togetheras they do in lifeworld certainties or in the overpowering authority of strong institutions withdrawn from any discussion-in an indissoluble amalgam. In the legal mode of validity the facticity of the state's enforcement of the law is interlocked with the validitygrounding force of a lawmaking process that claims to be rational because it guarantees liberty. ${ }^{40}$

\footnotetext{
${ }^{38}$ William Rehg, "Introduction" in Between Facts and Norms: Contribution to a Discourse Theory of Law and Democracy, W. Regh (trans.) (Cambridge: Polity Press, 1996), p. xiv-xx.

${ }^{39}$ Habermas, op.cit., supra note 17, p. 133.

${ }^{40}$ Ibid., p. 46.
} 
In other words, "[i]n the highly differentiated and pluralist societies, the tasks of social coordination and integration falls on to institutionalized procedures of legitimate lawmaking" which transform public opinions into binding decisions. ${ }^{41}$ At this point, Habermas indicates two dimensions of the tension between facticity and validity reflecting upon modern societies through law. When the tension between facticity and validity moves into the legal medium itself, called 'internal tension' by Habermas, it becomes visible in the legal claim to reach rational, certain, and predictable judgments as well as in its claim to perform coercive enforcement of legitimate orders. ${ }^{42}$ The 'external tension' between a claim of democratic-constitutional state to be legitimate and the actual perception of the state by its members appears "once law is reflexively applied to "the political' power. ${ }^{, 43}$ Habermas makes this external tension explicit in order to show how it can be bridged by law "as the means by which communicative reasons generated in a discursive opinion- and will-formation are transformed into collectively binding decisions." ${ }^{, 44}$ At this point, communicative power appears as a basis of legitimacy by reference to legitimate law-making procedures.

The next step for Habermas is to explain the reason which makes legal authority legitimate. His first target are legal positivists and also system theorist Niklas Luhmann, who adapts a legal positivist vision on this issue. According to Habermas, legal positivism reduces the conception of legitimacy to the legality of formal procedures. Against them, Habermas argues that nothing is given prior to the citizen's practice of

\footnotetext{
${ }^{41}$ Baynes, op. cit., supra note 1, p. 205.

${ }^{42}$ Ibid., p. 205. Habermas describes the internal tension both on the dimension of legal validity, which includes the tension between positivity and legitimacy of law, and inside the system of rights, which refers to the tension between private and public autonomy.

${ }^{43}$ Ibid., p. 136.

${ }^{44}$ Ibid., p. 206.
} 
self-determination other than the discourse principle, which is built in the conditions of communicative sociation in general, and the legal medium per se. That is to say, without recognition of legal order itself as legitimate the outcomes of legal procedures could not claim legitimacy.

The discussion of the legitimacy of legality brings Habermas to the central problem in Kant's political philosophy: his preference for subjective rights at the expense of objective rights, private autonomy at the cost of public autonomy. It is my contention that two factors create this dichotomy in Kant's philosophy: the limited character of his concept of 'publicity' and his subordination of law to morality. In his political writings, Kant develops a principle of 'publicity' which proposes that “[a]11 actions affecting the rights of other human beings are wrong if their maxim is not compatible with their being made public."45 At this point Chambers interpretation is significant: "[a]lthough the principle of publicity sets out the rudiments of a theory of political legitimacy, it is limited by the fact that Kant did not tie it to a theory of popular sovereignty." ${ }^{, 46}$ Moreover, the basis of civil society is established by reference to the Universal Principle of Law-or the Universal Principle of Right, which guarantees equal subjective liberty for all. In doing so, the legitimacy of law is removed from public discussion, and relied on a transcendental moral principle, which is unacceptable in post-metaphysical society. As a result, collective self-determination is subordinated to individual self-determination. ${ }^{47}$

\footnotetext{
${ }^{45}$ Immanuel Kant, "On the Disagreement between Morals and Politics in Relation to Perpetual Peace," in Kant: Political Writings, Hans Reiss (ed.), H. B. Nisbet (trans.) (Cambridge: Cambridge Press, 1991), p. 126.

${ }^{46}$ Simone Chambers, "Discourse and Democratic Practices," in The Cambridge Companion to Habermas, Stephen K. White (ed.) (Cambridge: Cambridge University Press, 1995), p. 236.

${ }^{47}$ Baynes, op. cit., supra note 1, p. 207. I argue that Kant's monological understanding of the individual is the basis of the problems in both his conceptualization of publicity and the
} 
Habermas wants to overcome this problem by means of his understanding of system of rights. His principal goal is to explicate the internal link between human rights and popular sovereignty in a 'system of rights' that is based on the equal value of private and public autonomy. ${ }^{48}$ For this reason, he insists on the complimentary relation between legal form and discourse principle. According to Habermas, the relation between positive law and individual liberty implies that as soon as individuals submit their will to join in social contract, which necessitates the regulation of common life by the legal form, they are granted an equal right to liberty. Even though legal form guarantees subjective rights, it alone cannot ground any specific right because participants are not Kant's intelligible characters, but real human beings developing their identities through intersubjective relations. Therefore, “a 'system of right' or 'rule of law' can be developed only if and when legal form is made use of political sovereignty in an exercise of citizens' public autonomy." ${ }^{, 49}$ This public autonomy refers back to discourse principle in two respects. While the discourse principle filters reasons, and information, topics and contributions in order to make the outcome of discourse rationally acceptable in relation to its cognitivist character, in the public sphere and parliamentary bodies, the discursive character of opinion- and will-formation forms relations of mutual understanding, which are violencefree. Here, we see an Arendtian reading. Briefly, since Habermas borrows his conception

subordination of public autonomy to private autonomy because the final decision is given by the individual by reference to the moral principle of universalization.

${ }^{48}$ Ingeborg Maus, "Liberties and Popular Sovereignty: On Jürgen Habermas's Reconstruction of the System of Rights," in Discourse and Democracy: Essays on Habermas's Between Facts and Norms, René Von Schomberg and Kenneth Baynes (eds.) (Albany: State University of New York Press, 2002), p. 91.

${ }^{49}$ Habermas outlines five basic categories of rights: the right to equal subjective liberties, the equal rights of membership in a voluntary association of citizens, the equal right to individual legal protection, the equal right to political self-determination, and the equal opportunity to utilize private liberties and political rights. While the first three categories secure the private autonomy, the last two categories refer to public autonomy. Habermas, op. cit., supra note 17, pp. 133-137. 
of power from Arendt, he specifies violence-free character of communicative action. These violence-free relations encourage the emergence of communicative power. ${ }^{50}$

At this point, it should be noted that Habermas clarifies the distinction between the principle of discourse and the principle of universalizability more precisely. In this sense, while the discourse principle, proposes that "[o]nly those norms can claim to be valid that meet (or could meet) with the approval of all affected in their capacity as participants in a practical discourse," moral and legal norms, the principle of universalizability emerges as a rule of moral argumentation which represents the specified version of the principle of discourse. This is followed by a simultaneous transformation of the principle of universalizability to the principle of democracy that specifies "a general procedure for legitimate lawmaking." ${ }^{, 52}$ It states: "Only those juridical statutes may claim legitimate validity that can meet with the agreement of all legal consociates in a discursive law-making process that in turn has been legally constituted." ${ }^{, 53}$ In this way, Habermas tries not to rely on the development of a system of rights either on a moral reading of human rights or on an ethical reading of popular sovereignty, but rather he tries to reconcile individual rights and democracy through the interpenetration of the legal form and the discourse principle.

However, the application of discourse ethics to democratic processes necessitates further explanation in the sense that it refers to 'the political' processes of the concrete and particular communities which include various practical questions in the name of both

\footnotetext{
${ }^{50}$ Arendt's conception of power will be explicated in relation to Habermas' conceptualization of political action in the next chapter. For Habermas' interpretation of Arendt's conception of power see Habermas, J., "Hannah Arendt: On the Concept of Power," in Philosophical-Political Profiles, Frederick G. Lawrence (trans.) (Cambridge: MIT Press, 1985).

${ }^{51}$ Habermas, op. cit., supra note 7, p. 66.

${ }^{52}$ Baynes, op. cit., supra note 1, p. 208.

${ }^{53}$ Emphasis added. Habermas, op. cit., supra note 17, p. 141.
} 
conflict resolution and goal attainment. For this reason, in the next section, I will explain which kinds of questions are raised in discursive opinion-and will-formation, and how these questions are dealt with recourse to the discourse principle.

\subsection{On the Employment of Practical Reason}

When certain problems are raised in highly differentiated and pluralist societies, the question of "What ought we to do?" is responded to by reference to the material in need of regulation. The meaning of 'ought' can be specified only if the relevant problem and the aspect under which it can be solved are determined. These problems can be defined along the lines of pragmatic, ethical, and moral issues, and three aspects such as the purposive, the good, and the moral. ${ }^{54}$

Pragmatic questions address the technical issue of finding the appropriate strategies and techniques for our wishes and values. In other words, the goal of practical reflection proceeding in the horizon of purposive rationality is to discover the appropriate techniques, strategies, or programs in accordance with value preferences and goal determination. ${ }^{55}$ In the case of pragmatic discourses, there is no internal relation between reason and will, because "the 'ought' of pragmatic recommendations relative to subjective ends and values are tailored to the arbitrary choice (Willkür) of a subject."56 But, if the values themselves become a problem, the question of "What should we do?" moves beyond the horizon of purposive rationality.

\footnotetext{
${ }^{54}$ For more details see Ibid., pp. 159-169; Jürgen Habermas, "On the Pragmatic, the Ethical, and the Moral Employments of Practical Reason," in Justification and Application: Remarks on Discourse Ethics (Cambridge: MIT Press, 1993), pp. 1-17.

${ }^{55}$ Ibid., p. 3.

${ }^{56}$ Ibid., p. 9.
} 
As a result of the dissolution of the metaphysical worldview, questions about the good life had been transferred to the questions of self-understanding and self-identity. "The 'ought' of clinical advice relativized to the telos of the good life is addressed to the striving for self-realization and thus to the resoluteness (Entschlußkraft) of an individual who has committed himself to an authentic life." ${ }^{, 57}$ Habermas sees a reciprocal relation between reason and will in the ethical-existential discourses. However, he claims that the will of the subject is always embedded within a life history, which is shaped by an intersubjectively shared form of life. In this respect, he relates ethical discourses to the tasks of goal attainment rather than conflict resolution. The discourses of conflict resolution deriving from opposed interests are acknowledged as moral discourses. ${ }^{58}$

From Habermas' point of view only the actions that affect the interests of others should be regulated from the moral point of view. In this sense, the moral discourses respond the question of "What is equally good for all?" In other words, moral discourses are associated with the just resolution of conflicts in the realm of norm-regulated action. In the case of moral discourses, "[t] he categorical 'ought' of moral injunctions, finally, is directed to the free will (freien Willen), emphatically construed, of a person who acts in accordance with self-given laws..." ${ }^{59}$ By adopting an impartial point of view, moral discourses create a significant break with both contingent dispositions and inclinations, and also with "all of the unquestioned truths of established, concrete ethical life." 60 This

\footnotetext{
${ }^{57}$ Ibid., p. 9.

${ }^{58}$ Ibid., p. 6.

${ }^{59}$ Ibid., p. 9.

${ }^{60}$ Ibid., p. 12. For more detail about the separation of morality from ethics see William Rehg, "Moral Discourse and Conceptions of the Good Life," in Insights and Solidarity: A Study in the Discourse Ethics of Jürgen Habermas (Berkeley: University of California, 1994); Jürgen Habermas, "Reply," in Habermas on Law and Democracy: Critical Exchanges, Michel Rosenfeld
} 
is the point that makes the will rational and hence autonomous. For example, questions of the education and health care system, and questions of tax law are identified as moral issues which "call for discourses that submit contested interests and value orientations to a universalization test within the framework set by system of rights as it has been constitutionally interpreted and elaborated."61 On the other hand, ecological questions, questions of abortion, or questions of ethnic minorities are identified with ethical discourses which engage participants in a hermeneutic process of self-clarification by which they become reflective about the common way of life. Habermas asserts that ethical discourses have an impartial dimension since they aim at an outcome that is equally good for all members of the collectivity. However, the impartiality of ethical discourses is more or less limited because they include only those who share the particular identity that is in question. ${ }^{62}$

At this point, Habermas indicates the difficulty of realizing these alternatives even under the ideal conditions because of the structure of complex societies. Therefore, he

and Andrew Arato (eds.) (Berkeley: University of California Press, 1998); McCarthy, op. cit., supra note 3, pp. 121-128.

${ }^{61}$ Habermas, op. cit., supra note 17, p. 165.

${ }^{62}$ Shane O'Neill claims that ethical discourses involve at two levels within a modern state: at state level, and at intrastate level. For example, when we ask questions like "What is it to be Turkish?" "What should Turkish state do to establish more democratic conditions?" O'Neill claims that these questions can be dealt with from an impartial point of view only to the extent that they aim at an outcome which is equally good for each and every Turkish citizen. But, at the intrastate level, ethical discourses involve a particular group of citizens. Such discourses could include Kurdish citizens, gays, women, and minority groups. A citizen can be involved in different groups in relation to her or his identity. Such questions can be raised by Kurdish citizens: "How can the Kurdish identity best flourish in Turkey?" "What are 'the political' goals of Kurdish citizens?" These questions can be dealt with in an impartial manner only if they aim at an outcome which is equally good for each and every Kurdish citizen in Turkey. Even though the number of people who are involved in the definition of "all" decreases, ethical discourses keep their impartiality in the name of abstracting ourselves from our own being. Shane O'Neill, "Morality and Ethical Life," in Impartiality in Context: Grounding Justice in a Pluralist World (Albany: State University of New York Press, 1997), p. 154. 
offers the alternative of bargaining, which involves negotiation between success oriented participants who are willing to cooperate. ${ }^{63}$ Habermas claims,

[b]argaining processes are tailored for situations in which social power relations cannot be neutralized in the way rational discourses presuppose. The compromises achieved by such bargaining contain a negotiated agreement (Vereinbarung) that balances conflicting interests. Whereas a rationally motivated consensus (Einverständnis) rests on reasons that convince all the parties in the same way, a compromise can be accepted by the different parties each for its own different reasons. However, the discursive chain of a rational will-formation would snap at such points of compromise if the discourse principle could not be brought to bear at least indirectly on bargaining processes. ${ }^{64}$

In other words, instead of deriving its power from better argument, bargaining derives its power from material resources or manpower. Therefore, it prevents the direct adaptation of the presuppositions of rationally motivated consensus. However, the discourse principle can be brought into play at least indirectly through procedures regulating bargaining process from the standpoint of 'fairness,' which provides equal distribution of non-neutralizable bargaining power among the participants.

However, it should be noted that Habermas disagrees with the idea of reducing political opinion-and will-formation to compromise because there is still a need to justify the presumption of fairness in moral discourses. Moreover, the only situation in which bargaining becomes necessary and permissible is the situation which includes only particular interests. But the necessity of bargaining can be tested only in moral discourses. At this point, it can be said that even though Habermas sees the impossibility of neutral power relations, he insists that they can be disciplined by procedures of fairness in bargaining process. However, it is my contention that fairness cannot be

${ }^{63}$ Habermas, op. cit., supra note 17, p. 165.

${ }^{64}$ Ibid., p. 166. 
realized fully if it is only understood in terms of procedures, which are shaped in accordance with the discourse principle, but it needs to be internalized by the participant of communities as a part of their identity. Moreover, he indicates that the results of ethical discourses must at least be compatible with moral principle in order to overcome the problem of the subordination of individual rights to collective goals. ${ }^{65}$ In other words, the last reference point for 'the political' will-formation has to call it 'rational.' Therefore, even though ethical discourses are included in discourse ethics, they are subordinated to moral discourses in the sense of their context-dependence. From this point, I want to consider Habermas' notion of deliberative politics in which autonomy appears as the self-determination of the participants.

\subsection{Deliberative Politics: A Procedural Concept of Democracy}

Habermas develops his understanding of politics from the critique of both liberal and republican understandings of politics. He attempts to incorporate the best characteristics of both models, while avoiding the shortcomings of each. Like the republican model, he rejects the interpretation of politics as conflicts of interests. However, more in keeping with liberal model, he criticizes republican model in the name of its vision of a citizenry as united and actively motivated by a shared concept of the good life. For Habermas, a shared ethos is almost impossible in the modern and pluralistic societies. He claims that

Discourse theory has the success of deliberative politics depend not on a collectively acting citizenry but on the institutionalization of the corresponding procedures and conditions of communication, as well as on the interplay of institutionalized deliberative processes with informally constituted public opinions. ${ }^{66}$

\footnotetext{
${ }^{65}$ Ibid., p. 167.

${ }^{66}$ Ibid., p. 333.
} 
In deliberative politics, the goal is not defined as a shared ethos, but rather in terms of the formation of rational political opinion. As mentioned above, pragmatic and ethical discourses, as well as moral discourses, are involved in democratic opinion-and willformation processes. All of these discourses are governed by the rules of equality, freedom, and fair play; and all of them are directed at mutual understanding through practical argumentation in which critical validity claims are raised. However, here it should be noted that mutual understanding does not only include consensus, but also compromise. Thus, the emphasis is shifted from the final act of voting and/or the problems of social choice to the argumentation process itself and the participants' adoption of an impartial point of view. To put it differently, "the aim of deliberative politics is to provide for the transformation of preferences in response to the considered views of others and the 'laundering' or filtering of irrational and/or morally repugnant preferences in ways that are not excessively paternalistic."67 It can be claimed that Habermas relies for the success of the discourses on the participants' adoption of an impartial point of view. According to him, once the moral point of view is adopted, participants will be able to be open to a dialogue and mutual understanding in the sense that they will recognize each other as abstract subjects.

Habermas' concept of 'the political' is built on his understanding of 'communicative power.' As mentioned above, he borrows Arendt's notion of power which emphasizes that power cannot be possessed by any one: "[p]ower springs up between men when they act together, and it vanishes the moment they disperse.",68 In

\footnotetext{
${ }^{67}$ Emphasis added. Baynes, op. cit., supra note 1, p. 216.

${ }^{68}$ Hannah Arendt, The Human Condition (Chicago: University of Chicago Press, 1958) (second edition), p. 200.
} 
criticizing republicanism, he claims that "the notion of communicative power should not be understood too substantively as the (more or less) spontaneous expression of common will but rather as the product of an overlapping and intermeshing of a variety of (more or less) institutionalized pragmatic, ethical, and moral discourses." 69 From Habermas' point of view, communicative power is the realization of a rational public opinion-and will-formation in a process of legitimate lawmaking which consists of a complex network of processes of reaching understanding and bargaining. ${ }^{70}$ In this regard, the legitimate exercise of power can only emerge through the medium of law which has to be tied to the public sphere. In other words, the 'rule of law' should become the rule of people through a rational opinion- and will-formation in the public sphere. But, the essential point for deliberation is

less that everyone participate-or even that voting be made public - than that there be a warranted presumption that public opinion is formed on the ground of adequate information and relevant reasons and that those whose interests are involved have an equal and effective opportunity to make their own interests (and reasons for them) known. ${ }^{71}$

In the democratic 'rule of law', Habermas divides political power into communicative power and administrative power, which generates a two-track process necessitating a division of labor between 'weak publics' - the informally organized public sphere ranging from private associations to the mass media located in 'civil society' - and 'strong publics'-parliamentary bodies and other formally organized institutions of 'the political' system. Habermas sees the 'weak publics' as the means for public opinion in which the opinion formation is decoupled from decisions. The

\footnotetext{
${ }^{69}$ Baynes, op. cit., supra note 1, p. 213.

${ }^{70}$ Ibid., p. 213.

${ }^{71}$ Ibid., p. 216. For more details see Habermas, op. cit., supra note 17, pp. 147-157.
} 
reconciliation of opinion formation and decision-making is realized in strong publics. Even though the general public sphere is vulnerable to the repressive and exclusionary implications of unequally distributed social power, structural violence, and systematically distorted communication, it has the advantage of being a medium of unrestricted communication, which is seen as the sole source of solidarity in modern societies. ${ }^{72}$ Although Habermas mentions the division of labor between weak and strong publics, he does not clarify how this relation is to be mediated. In the next section, I will attempt examine the limitations of Habermas' concept of 'the political'.

\subsection{Imprisonment of 'the Political' in the Formal Logic of Legislation}

Habermas' conceptualization of 'the political' finds its roots in his defense of modernity; he claims that the potentiality of rationality has not yet been realized. Contrary to Frankfurt School's pessimism about instrumental rationality and the skepticism of post-modernists about the repressive role of rationality, Habermas develops his concept of deliberative politics by reference to communicative rationality by which he retains the Kantian idea of the power of reason. He starts from the critique of the onesided rationalization of modern society and the colonization of the lifeworld by system

\footnotetext{
${ }^{72}$ Habermas' concept of public sphere finds its roots in his first book, Structural Transformation of Bourgeois Society (1989). On the one hand, the idea of a public sphere is interpreted as an institutional mechanism for rationalizing political domination by rendering the state accountable to the citizens; on the other hand, it is read as to designate a specific kind of discursive interaction by which unrestricted rational discussion of public matters is realized. However, Habermas' understanding of public sphere is criticized by recent revisionist historiography because of his idealization of the liberal public sphere. While Habermas argues that the discussion is open and accessible to all, the revisionist historiography claims that even though there was the rhetoric of publicity and accessibility, the official public sphere rested on significant exclusions, as mentioned above. For more details see Nancy Fraser, "Rethinking the Public Sphere: A Contribution to the Critique of Actually Existing Democracy," in Habermas and the Public Sphere, Craig Calhoun (ed.) (Cambridge, Mass: MIT Press, 1992), pp. 109-142. For more details see also Habermas, op. cit., supra note 17, pp. 307-308.
} 
mechanisms in the name of instrumental rationality. Then, he reconstructs the public sphere as a site of critique in which practical argumentation takes place within the limitations of discourse ethics. This is the point from which his theory is opened to the theory of law in the name of 'institutionalization' of both subjective rights and presuppositions of the discourse. Even though Habermas develops a deliberative understanding of politics, his concept of 'the political' remains limited in the sense of "the abstractness of the modern autonomous subject and the inevitable emptiness of formal principles grounded solely in the constraints of an unsituated reason." ${ }^{, 73} \mathrm{My}$ argument is that Habermas' concept of 'the political' cannot provide a satisfactory alternative to liberal democracy, in contrast, it reduces the emancipatory potential of politics to a formal, procedural restatement of the liberal 'rule of law'. In doing so, he eliminates the agonistic, civic, and performative aspects of politics.

In his notion of deliberative politics, Habermas has aimed to show the cognitivist basis of democracy in the disenchanted world in which traditional and religious transcendental foundations have reached their end, value pluralism has simultaneously risen, and distinct life-orders have become autonomous. For this reason, he "deduces the normative content of discursive democracy from the rational presuppositions of speech." ${ }^{, 74}$ Moreover, he secures the actualization of the presuppositions of discourse by means of legal institutionalization. In doing so, he removes practical reason from "the hearts and heads of collective or individual actors into the procedures and forms of communication of political opinion- and will-formation." 75 In other words, the effectiveness of practical reason is transferred from the mentality of citizens to the

\footnotetext{
${ }^{73}$ Cronin, op. cit., supra note 4, p. xxi.

${ }^{74}$ Kalyvas, op. cit., supra note 36, p. 4.

${ }^{75}$ Habermas, op. cit., supra note 62, p. 385.
} 
deliberative forms of politics. This relies on his differentiation of morality from ethics, and the declaration of the superiority of 'right' over 'good,' which generates two significant limitations of 'the political.'

Firstly, for Habermas, "political autonomy refers to the rational testing of the validity of social and political norms and not to their creation." ${ }^{, 76}$ In other words, political autonomy is exclusively related to the moment of opinion formation, and is disconnected from decision-making. The transformation of decision-making processes into institutionalized, formal publics, citizens' active and effective involvement in the lawmaking process is prevented. It is my contention that the total divorce of decision-making from an active involvement of citizens involves two risks: on the one hand, it could generate the invasion of the lifeworld by the modern bureaucratic capitalist state and its professional officials. On the other hand, it could reproduce depoliticized society with reference to citizens' belief in their powerlessness with respect to 'the political' system. In other words, Habermas' notion of deliberative politics retains the ruling power of 'the political' system over the public sphere.

Secondly, by the identification of conflict resolution only with the validity claims of moral norms, and hence the exclusion of self-realization from the notion of political autonomy the subjects' potential for questioning the given reality and the claims for recognition on the basis of the particularity of subjects are limited. Even though ethical questions are included in the employment of practical reason by reference to the issues of goal attainment, they are subordinated to moral questions in the case of conflict resolution. In this sense, according to Habermas, in highly differentiated and pluralist societies, an ethically controversial issue should not be regulated under the ethical

${ }^{76}$ Kalyvas, op. cit., supra note 36 , p. 6. 
discourse defined by self-clarification, but rather it should be regulated by moral discourse representing a more abstract level in which the different ethically integrated communities have equal right to coexist. The change in the level of abstraction necessities a shift in perspective from ethical to moral since the ethical aspect is limited to a particular context, a specific community, while the moral aspect transcends all the boundaries. He says

[e]ach participant must turn away from the ethical question of which regulation is respectively "best for us" from "our" point of view. They must, instead, take the moral point of view and examine which regulation is "equally good for all" in view of the prior claim to an equal right to coexist."

It is my contention that Habermas' sharp separation between the questions of the right and the good generates a defect in his theory by retaining Kantian formalism. Even though he accepts that "practical judgments derive both their concreteness and their power to motivate action from their inner connection to unquestionably accepted ideas of the good life, in short, from their connection to ethical life and its institutions," the disposition of participants in discourse is associated with the formal principles of practical argumentation. This necessitates the abstraction of participants from the concrete content of duties and maxims. In other words, democratic deliberation is reduced to the impersonal or subjectless procedures and structures, which do not include any reference to forms of subjective attitudes, orientations and motivations, which give procedures their meaning and validity. ${ }^{78}$

\footnotetext{
${ }^{77}$ Habermas, op. cit., supra note 60, p. 393.

${ }^{78}$ Andrew Buchwalter, "Habermas, Hegel, and the Concept of Law," in Discourse and Democracy: Essays on Habermas's Between Facts and Norms R. Von Schomberg, and Kenneth Baynes (eds.) (Albany: State University of New York Press, 2002), pp. 130-131.
} 
However, discourse depends not only on institutionalizing the necessary procedures and conditions of communication, but also citizens' participation in both institutionalized and informal discourse. At this point, it can be said that Habermas assumes the willingness of citizens to become involved in the discursive opinion-and will-formation. If people do not participate, it is not a matter how well or functional designated procedures are because they cannot function without participation. The following question is significant in this respect: what could be the motivation for people to become involved in discourse, especially in the case of Habermas' deliberative politics in which politics is transposed from the realm of collective struggle to the sphere of abstract speculation? As an answer to this question, Habermas would say "nothing better prevents others from perspectivally distorting one's own interests than actual participation. It is in this pragmatic sense that the individual is the last court of appeal for judging what is in his best interest." ${ }^{, 79}$ Even though this assertion evokes the liberal understanding of politics in which self-interests form the principal motivation of politics, Habermas differentiates his notion of 'the political' from liberalism with resort to participants' usage of political liberties in the service of mutual understanding or what Kant called the 'public use of reason. ${ }^{, 80}$ But, this answer raises another question: what motivates participants for the public use of reason in highly differentiated and pluralist societies? According to him, there are two imperatives for the public use of reason: a liberal public space requiring free form of association, domesticated media power, and liberal political culture of a population accustomed to freedom, and a rationalized

\footnotetext{
${ }^{79}$ Habermas, op. cit., supra note 7, p. 67.

${ }^{80}$ Habermas, op. cit., supra note 60, p. 385 .
} 
lifeworld in which post-conventional ego-identities are developed ${ }^{81}$ In other words, liberal political culture needs to be met halfway by a more or less rationalized lifeworld. However, Habermas is criticized for idealizing the liberal public sphere in the name of equal participation of all in deliberation. Contrary to Habermas, some revisionist theorists argue that in spite of the rhetoric of publicity and accessibility, the official public sphere includes significant exclusions. For example, Joan Landes claims that gender is a key axis of exclusion in liberal public sphere, while Geoff Eley describes the public sphere as a training ground, and the power basis of bourgeois men who define themselves as a 'universal class.' These critiques draw attention to the reality that even in the absence of formal exclusion, deliberation can serve as a mask for domination in the name of unequal relations of gender, class, and ethnicity. ${ }^{82}$ In other words, the inclusion of the other in procedural terms cannot be sufficient to overcome asymmetries in access to information as well as unequal distribution of competences and knowledge if the procedures and institutions of political community are not internalized by the participants. In this sense, formal inclusion of the other can only be a means of politics, rather than the goal of politics. At this point, it should be noted that even though Habermas attributes postconventional ego-identities to all the participants, neither the increase of nationalist movements nor the depoliticization process in post-metaphysical era support his assumption. In other words, his attribution of post-conventional ego-identities to participants fails to correspond to the personality structure of most citizens.

\footnotetext{
${ }^{81}$ Jürgen Habermas, "A Conversation about Questions of Political Theory," in Discourse and Democracy: Essays on Habermas's Between Facts and Norms, R. Von Schomberg, and Kenneth Baynes (eds.) (Albany: State University of New York Press, 2002).

${ }^{82}$ Fraser, op.cit., supra note 72, pp. 112-119.
} 
Moreover, since Habermas understands mutual recognition only at the abstract level of self-determination, subjects' personal freedom that derives from their concrete existences in ethical life cannot be problematized in deliberative politics. Thus, politics is imprisoned in the formal logic of self-legislation. Sandel states that

[a]s bearers of rights, where rights are trumps, we think of ourselves as freely choosing, individual selves, unbound by obligations antecedent to rights, or to the agreements we make. And yet, as citizens of the procedural republic that secures these rights, we find ourselves implicated willy-nilly in a formidable array of dependencies and expectations we did not choose and increasingly reject. $^{83}$

This approach is also fed by Habermas' continuation of the liberal view of the autonomy of 'the political.' By advocating the compartmentalization of social life such as politics, economy, and culture, he claims that the state should take a neutral position in order not to take sides among different definition of the 'good life.' However, this idea itself relies on a specific definition of the 'good life.'

In conclusion, since Habermas sees modernity as an 'unfinished project', he attempts to address how to protect and expand the sphere of communicative action which consists of an emancipatory potential. This potential is actualized through a transition from action to argumentation, from norm-guiding action to norm-testing discourse. By attributing decentralized consciousness to participants and by drawing the boundaries of argumentation in terms of moral principles, he suggests not only a utopia, but also a limited conception of the public sphere. In the following chapter, against Habermas' limited notion of moral politics, I will suggest an Arendtian conceptualization of 'the political.' For this purpose, in the first section, I will attempt to explain the public sphere

${ }^{83}$ Michael J. Sandel, "The Procedural Republic and the Unencumbered Self," Political Theory 12 (1) (February 1984), p. 94. 
in Arendt's account by reference to the public sphere as a 'space of appearance' and as a 'world in common.' In the second section, I will explicate plurality and freedom in relation to Arendt's conceptualization of 'the political.' Finally, I will elucidate the relation between morality, ethics and politics from Arendt's point of view. Within each section, I will attempt to denote my comparison between Arendt and Habermas and my reasons for espousing an Arendtian perspective. 


\section{CHAPTER 3}

\section{AN ALTERNATIVE TO 'MORAL POLITICS' FROM AN ARENDTIAN PERSPECTIVE}

“...there is no such substratum; there is no 'being' behind doing, effecting, becoming; 'the doer' is merely a fiction added to the deed - the deed is everything."

Nietzsche

Habermas' main concern is to appease distortions and pathologies of one-sided rationalization of the modern society and, in particular, to shelter the sphere of communicative action against systemic imperatives of economy and administration by means of morality and to secure it through the 'rule of law.' His matter of concern leads him to develop a conception of 'the political' from within 'the social' in the Arendtian terms. In doing so, he draws the boundaries of the public sphere via moral principles, i.e. the principle of discourse, which filters opinions and information, topics and contributions to the public sphere, and the principle of universalizability, which demands an adaptation of a moral point of view. His conceptualization of 'the political' therefore sacrifices plurality for the sake of 'consensus' and, in turn, generates conformity in the public realm.

In this chapter, I will reflect upon Arendt's agonistic notion of 'the political' and argue that Arendt's original attempt to reactivate an ancient notion of praxis represents a potential alternative to Habermas' 'moral politics.' In this sense, I will focus on Arendt's theory of action and her theory of judgment by which she defines "judgment with phronesis on the grounds that both are capacities of political actors, and that both are 
rooted in sensus communis." By differentiating praxis (action) from poiesis (fabrication) with reference to the action's connection to freedom and plurality, and by showing its relation to speech and remembrance, she creates a conception of 'the political' by which "questions of meaning, identity and value can be addressed in a pertinent manner.", Moreover, she presents a defense of participatory democracy by seeing action as a mode of human togetherness in direct contrast to the bureaucratized forms of politics which symbolize the modern epoch.

For Arendt action represents the category around which political life is centered and constitutes the highest realization of the vita activa. ${ }^{3}$ By defining plurality as the condition of all political life and freedom as inherent in action, she renders action, 'virtuosity,' an excellence attributed to performing arts in which accomplishment lies in performance itself, and becomes the goal of political action. In this sense, the public sphere appears as a realm in which individuals disclose the unique identities inherent in their births. It appears as a spontaneity of 'agora' in which agreement is possible as much as disagreement, consent is possible as much as dissent; rather than a 'seminar room' whose illuminations are more controllable. She thus frees 'the political' from the chains of the 'means-ends' category.

\footnotetext{
1 Maurizio Passerin D'Entréves, "Hannah Arendt's Theory of Judgment," in The Political Philosophy of Hannah Arendt (London: Routledge, 1994), p. 121.

${ }^{2}$ Maurizio Passerin D'Entréves, "Freedom, Plurality, Solidarity: Hannah Arendt's Theory of Action," Philosophy and Social Criticism 15 (4) (1989), p. 307.

${ }^{3}$ In the Human Condition, vita activa is analyzed qua three categories that correspond to the three fundamental activities of our "being-in-the-world." In this sense, labor as an activity corresponds to the human condition of life itself, work corresponds to worldliness, and action corresponds to plurality. Moreover, natality and mortality are defined as general human conditions. Her differentiation among labor, work and action goes beyond the scope of this thesis; I will mainly focus on her theory of action. For more details see Hannah Arendt, The Human Condition (Chicago: University of Chicago Press, 1958) (second edition, 1998), pp. 7-11, 79-248.
} 
While Arendt's concept of action forms a central category of her political thought, it is matched by judgment as the faculty which evaluates actions. For her, judgment is intrinsically related to the essential plurality of human beings, it is related to the 'world we have in common.' Matters of praxis, belonging to this common world, are neither susceptible to scientific proof, nor are they matters of knowledge, rather of opinion. At this point, the theory of phronesis appears to explicate the difference between 'good' and 'bad' judgment with reference to the field of human praxis. The field of this human praxis is neither an existing 'ethical totality,' nor subjectless argumentation process, but a regulative idea, the sensus communis (common sense). What is crucial when conveying Arendt's conception of judgment is her understanding of the relation between morality, ethics and politics in relation to 'disinterestedness' and 'common sense.'

\subsection{The Public Realm:}

Arendt's concept of 'the political' is inspired by her critical engagement with modernity which centers on the ways in which an emergent social condition, namely 'the rise of the social' and the development of totalitarianism, generates the collapse of the distinction between private and public spheres. This distinction between private and public, she claims, coincides with the "opposition of necessity and freedom, of conformity and uniqueness, of futility and permanence." ${ }^{4}$ The elimination of the division thus blurs these oppositions. According to Arendt, the private is the sphere of the household 'born of necessity,' and which corresponds to activities that are related to the maintenance of life, whereas public is the sphere of freedom, of the disclosure of the 'who' via speech and action, and which corresponds to activities that are related to a common world.

\footnotetext{
${ }^{4}$ Ibid., p. 73 .
} 
The rise of 'the social' from the interior of the household into the 'light of the public space' has not only blur the frontier between private and political, but it also changes their meaning and significance for the life of the individual and the citizen. ${ }^{5}$ The activities, problems and organizational devices of household become public concerns and, in turn, the private is defined as a sphere of intimacy whose relevant function is to shield the intimate. Meanwhile, the matter of the public realm has transformed from what was deemed as freedom to 'sheer survival,' therefore, 'our capacity for action and speech has lost much of its former quality since the rise of the social realm banished these into the sphere of the intimate and the private." ${ }^{\prime 6}$ To express it differently, the public realm is conquered by conformity and uniformity and, in turn, freedom becomes a matter of concern for the sphere of 'intimacy.' However, Arendt argues that each human activity has a proper space in which to take place. If one of them transgresses the space of another, it deprives the other of its autonomy and generates something entirely different.

In Arendt's view, the 'public' indicates two closely interconnected but not altogether identical phenomena: the public realm as a 'space of appearance' and the public realm as a 'world we hold in common.' According to the first meaning, the public realm is the space in which everything can be seen and heard by everybody, and in this respect has the broadest possible publicity. This appearance can be actualized only through action (praxis) and speech (lexis), from which the realm of human affairs arises. 'To act,' in its widest sense, means to "take an initiative, to begin, to set something into motion."7 Following Augustine, Arendt argues that by virtue of the human condition of natality, new comers and beginners are incited into action through which they can reenact the miracle of beginning inherent in their birth. Action in this sense can be seen as a

\footnotetext{
${ }^{5}$ Ibid., p. 38.

${ }^{6}$ Ibid., p. 49.

${ }^{7}$ Ibid., p. 179.
} 
second birth whereby individuals enter into the world in which their act can be seen, heard and judged, and hence, they disclose their 'who-ness.' This disclosure of who somebody is becomes visible with both in her or his words and deeds since without the words deeds can only be perceived in "its brute physical appearance." Therefore, Arendt sees action and speech "coeval and coequal, of the same rank and the same kind." Briefly, by calling something into being "which did not exist before, which was not given, not even as an object of cognition or imagination," action demonstrates creativity and unpredictability. ${ }^{9}$ On the other hand, action as a certain kind of speech, whose distinctive features are debate and deliberation, argument and persuasion, provides a noncoercive and non-violent form of being and acting together.

She argues that "our feeling for reality depends utterly upon appearance and therefore upon the existence of a public realm into which things can appear out of darkness of sheltered existence." 10 To put it differently, the public realm as a "space of appearance' is the space in which and through which reality is constituted since "the presence of others who see what we see and hear what we hear" assures us of the reality of the world as well as of ourselves and we share words and deeds, evaluate actions, and reveal our identities via this 'space of appearance.' More succinctly, the public realm provides the light and the publicity which are necessary for the formation of our public identities, for the recognition of a common world, and for the assessment of the actions of others.

The 'space of appearance' emerges whenever individuals gather together in the "manner of speech and action," and "therefore predates and precedes all formal

\footnotetext{
${ }^{8}$ Ibid., p. 26.

${ }^{9}$ Hannah Arendt, "What is Freedom?" in Between Past and Future: Eight Exercises in Political Thought (New York: Viking Press, 1961), p. 151.

${ }^{10}$ Arendt, op. cit., supra note 3, p. 51.
} 
constitution of the public realm and the various forms of government, that is, the various forms in which the public realm can be organized." 11 That is to say, it is not restricted to a set of institutions or to a specific location; rather, it may arise suddenly, as in the case of revolution or it may arise gradually out of the efforts to change specific pieces of government policies, i.e. preventing the establishment of a nuclear energy station, legalizing gay marriage, or extending public education. D'Entréves notes “town hall meetings of worker's councils, from demonstration and sit-ins to struggles for justice and equal rights" as the historical examples of the creation of the 'space of appearance.'

Calhoun argues that Arendt's notion of the public realm as the 'space of appearance' allows us to acknowledge the possibilities for political action "instantiating multiple, overlapping, and sometimes conflicting public domains."12 In this sense, Arendt's notion of the public realm, I suggest, persuasively challenges Habermas' account of 'the public sphere' persuasively. In his account, Habermas reduces 'the light of the public' to 'the light of reason' by depicting the public with reference to an "institutionally protected and procedurally defined sphere" which is a pivotal setting for 'communicative action.' Thus, the public sphere emerges as a comprehensive, unitary, integrated and fixed realm secured by institutions and law. However, it is my contention that this singular public realm cannot avoid "absorbing less powerful into a false 'we' that reflects more powerful"' as in the liberal public sphere.

I think that in this single and fixed public realm the possibilities for political action cannot be recognized. In this respect, it becomes exclusive to plurality and difference. Habermas attempts to prevent this situation by defining a discursive public

\footnotetext{
${ }^{11}$ Ibid., p. 199.

${ }^{12}$ Craig Calhoun, "Plurality, Promises, and Public Space," in Hannah Arendt and the Meaning of Politics, Craig Calhoun and John McGowan (eds.) (London: University of Minnesota Press, 1997), p. 239.
} 
realm. However, this strictly discursive public realm itself requires the hegemony of a given paradigm of argumentative rationality based on the principles of discourse and universalizability. Therefore, those discourses, or rhetorics which depart from or challenge the argumentative rationality cannot attain the 'force of better argument.' Indeed, by declaring that people who oppose the principles of discourse fall into the 'performative contradiction,' Habermas demonstrates an exclusionary and singular character of the public sphere. On the contrary, in Arendt's account, the 'space of appearance' does not necessitate specific institutions, settings, or procedures; "it arises out of action and speaking together, and its true space lies between people living together for this purpose, no matter where they happen to be." ${ }^{13}$ But, this space does not always exist; whenever people come together, it is just “...potentially there, but only potentially, not necessarily, and not forever." 14

This 'potential' character of the 'space of appearance' is defined the concept of power. The public realm, Arendt claims, can emerge and endure only via power:

[p]ower cannot be stored up and kept in reserve for emergencies, like the instruments of violence, but exists only in its actualization... [It] is actualized only where word and deed have not parted company, where words are not empty and deeds are not brutal, where words are not used to veil intentions but to disclose realities, and deeds are not used to violate and destroy but to establish relations and create new realities. ${ }^{15}$

\footnotetext{
${ }^{13}$ Arendt, op. cit., supra note 3, p. 198.

${ }^{14}$ Ibid., p. 200.

${ }^{15} \mathrm{Ibid}$., p. 200. Arendt differentiates power from strength, force and violence. By her definition, strength refers to the property inherent in an object or a person; therefore, it cannot be shared. Unlike strength, power is created by a group of people who are acting in concert for the sake of political purposes, and it remains in existence as long as they stay together. Force is a natural phenomenon imposed by the situation, whereas power is a human creation. Violence represents the imposition of one's will upon others, which is called coercion. Unlike violence, power depends on deliberation. For more details see Ibid., pp. 201-203.
} 
In other words, "power springs up between people when they act together and vanishes the moment they disperse." ${ }^{\prime 16}$ Therefore, power is independent of material factors such as numbers and means; rather the sine qua non of power is the 'human togetherness.' In her claim, Arendt stresses the performative character of "the acted deed and the spoken word," to the fact that they are independent of "victory and defeat and must remain untouched by any eventual outcome, by their consequences for better or worse." ${ }^{, 17}$ In adopting Aristotle's notion of energia (actuality), she argues that action does not pursue an end and leave any work behind; rather "the end (telos) lies in the activity itself... and the work is not what follows and extinguishes the process but is imbedded in it; the performance is the work, is energia" since the term 'work', in this context, is depicted as "acting well and living well." 18 To express it differently, the 'work of man qua man' is the only way to surmount the means-ends category since the means to achieve the endto form and manifest our identities - "would already be the end; and this 'end,' conversely, cannot be considered a means in some respect, because there is nothing higher to attain than this actuality itself."19 This is the reason for Arendt to claim that "[m]en are free-as distinguished from their possessing the gift for freedom-as long as they act, neither before nor after; for to be free and to act are the same."20 By defining freedom as inherent in action, 'virtuosity,' an excellence attributed to performing arts in which accomplishment lies in performance itself, becomes the goal of political action.

\footnotetext{
${ }^{16}$ Ibid., p. 200.

${ }^{17}$ Ibid., p. 205.

${ }^{18}$ Ibid., p. 206.

${ }^{19}$ Ibid., p. 207. According to Arendt, the convictions of both animal laborans and homo fabers are unpolitical since they would judge public activities in terms of their 'usefulness' in relation to higher ends. In the case of animal laborans, these ends are defined to satisfy the chain of vital necessities in the best way, whereas in the case of homo fabers they are defined to make the world more useful and beautiful. Therefore, neither labor nor work can be free from necessity and usefulness, and in turn, the means-ends category. For more details see Ibid., pp. 7-11, 207-220.

${ }^{20}$ Ibid., p. 153.
} 
This performative dimension of political action, Arendt claims, generates power, which "keeps people together after the fleeting moment of action has passed and what they keep alive through remaining together" because there is an utter dependence upon further acts to keep the public sphere in existence. ${ }^{21}$ In other words, power is making and remaking the public realm - the potential 'space of appearance'-through collective action and public deliberation.

It is worth noting that Habermas' interpretation of Arendt's conception of power refers to its law making and founding capacity rather than its performative character. According to Habermas, Arendt conceives political power "as an authorizing force expressed in 'jurisgenesis' - the creation of legitimate law-and in the founding of institutions. It manifests itself in orders that protect political liberty; in resistance against the forms of repression that threaten political liberty internally or externally..."22 I argue that since Habermas stresses 'making and founding' capacity of political power rather than its spontaneous and performative character, he characterizes political power by reference to its end product, i.e. making legitimate law, rather than being an 'end in itself.' In doing so, he refers to the public sphere as the 'work of human hands,' but not as the 'work of man.' However, the 'work of human hands' and the 'work of man' are different sides of the same coin which symbolizes the public sphere.

The 'space of appearance' emerges as the 'work of man' is highly fragile and transitory. In contrast to its fragile and short-lived character, the second meaning of the 'public' as a 'world we hold in common' provides durability and permanence by being a human artifact or a fabrication of human hands:

\footnotetext{
${ }^{21}$ Ibid., p. 201.

${ }_{22}$ Jürgen Habermas, Between Facts and Norms: Contribution to a Discourse Theory of Law and Democracy, William Regh (trans.) (Cambridge: Polity Press, 1996), p. 148.
} 
Life in its non-biological sense, the span of time each man has between birth and death, manifests itself in action and speech, both of which share with life its essential futility. The "doing of great deeds and the speaking of great words" will leave no trace, no product that might endure after the moment of action and the spoken word has passed...[unless] the man-made world of things, the human artifice erected by homo faber, becomes a home for mortal men. ${ }^{23}$

To put it differently, action and speech as the most futile of human activities, and words and deeds as the most ephemeral and the least tangible of the 'work of man' would become everlasting through human artifacts and institutions which facilitate individuals 'feeling at home' in the world and able partially transcend the fleetingness of their existence. Arendt illustrates these human artifacts by reference to the organization of the polis that was "physically secured by the wall around the city and physiognomically guaranteed by its law." ${ }^{24}$ However, neither the wall of the polis nor the boundaries of the law were preconditions of the public realm; rather, they were drawn around an already existing public space. That is to say, the 'spaces of appearance' are not constituted or conditioned by institutionalization, but by political action.

Arendt's conceptualization of the public realm as a sphere that cannot exist without political action decisively differentiates from Habermas' notion of the public realm. In his view, political action in the widest sense of the word, argumentation, demands a specific rationalization process through which private and public autonomy are reconciled. This process signifies the institutionalization of private rights as well as the procedures of the public sphere. As noted above, the 'public' emerges as an "institutionally protected and procedurally defined sphere" which is an indispensable precondition for argumentation. The most significant reason for Habermas to constitute

\footnotetext{
${ }^{23}$ Ibid., p. 173.

${ }^{24}$ Ibid., p. 198.
} 
the public realm as a precondition for political action is the "fragility of communicative life forms' and the fact that "socialized individuals are in need of peculiar protection."25 Similar to Kant, Habermas thinks that the means for this "peculiar protection" lie in morality. In this respect, he defines morality as "a device woven with the threads of communication to shield the peculiar vulnerability of socialized individuals. $" 26$ In order to ensure such protection he opts for predictability. He establishes his predictability with resort to the Kantian categorical imperative and the universalizability that it implies. Thus, Habermas holds on to morality which shelters socialized individuals from the threads of the communication process. Law, in turn, has the function of supporting and protecting morality by stabilizing behavioral expectations. However, in his attempt, he sacrifices human plurality and openness to radical changes in favor of conformism and stability. At this point, it seems plausible to follow the Arendtian line which argues that "[t]he limitations of law are never entirely reliable safeguards against action from within the body politic, just as the boundaries of the territory are never entirely reliable safeguards against action from without."27

While Habermas strives to justify the predictability of action through intuitive knowledge of moral principles and the application of democratic procedures, Arendt celebrates the contingent character of action including its boundlessness and unpredictability. Since, Arendt claims, action takes place within a 'web of human relationship,' it "acts into a medium where every reaction becomes a chain reaction and where the very process is the cause of new processes."28 Therefore, the consequences of action are boundless; namely, the actor is not only a 'doer' but also a 'sufferer' of her or

${ }^{25}$ Jürgen Habermas, "Public Space and Political Public Sphere-the biographical roots of two motifs in my thought," Commemorative Lecture, Kyoto Nov.11 2004).

${ }^{26}$ Ibid., p. 5.

${ }_{27}^{27}$ Arendt, op. cit., supra note 3, p. 191.

${ }^{28}$ Ibid., p. 190. 
his deeds and words. In her interpretation, Arendt portrays creativity and boundlessness of action as the opposite sides of the same coin. One side of the coin represents tremendous capacity of action for establishing relations and hence its "inherent tendency to force open all limitations and cut across all boundaries," ${ }^{29}$ whereas the other side symbolizes our inability to foretell all the logical consequences of a particular act since action has no end. Arendt does not see this boundlessness as a threat, but only the other side of the specific productivity of action. But, she draws attention to the limitedness of human artifacts to set limitations and boundaries upon the consequences of action, and stresses the virtue of moderation, "of keeping within bounds" as a way of surmounting it. ${ }^{30}$ She argues that "while the various limitations and boundaries we see in every body politic may offer some protection against the inherent boundlessness of action, they are altogether helpless to offset its second outstanding character: its inherent unpredictability." 31 Unpredictability stems from the fact that the full meaning of action can only reveal itself when it ends because there is no determined end, image or model perceived in advance as in fabrication, but only in performance itself. In other words, the goal of political action and deliberation as an 'end-constitutive' process that "does not stand apart from the process, dominating it at every point, but is rather formed in the course of the performance." 32 In this sense, it can be said that Arendt's celebration of contingency as a structural feature of action is replaced by Habermas' anxiety to get a

${ }^{29}$ Ibid., p. 190.

${ }^{30}$ The virtue of moderation is one of the political virtues par excellence. Arendt's emphasis on the virtue of moderation instead of human artifacts illustrates the relation between the ethical and 'the political' in her thought. The difference between Arendt and Habermas in terms of a relation between the ethical, moral and 'the political' will be discussed in the third section of this chapter. ${ }^{31}$ Ibid., p. 191.

32 Dana R. Villa, Arendt and Heidegger: The Fate of the Political (Princeton: Princeton University Press, 1996), p. 32. 
grip on the 'fragility of communicative life forms.' Therefore, the spontaneous light of the public realm is altered by the more controllable illuminations of the seminar room.

In Arendt's account, the second meaning of the 'public' as a 'world we hold in common' is also related "to the affairs which go on among those who inhabit the manmade world together." ${ }^{33}$ This is the world which is "common to all of us and distinguished from our privately owned place in it." ${ }^{34}$ Thus,

[t]o live together in the world means essentially that a world of things is between those who have it in common, as a table is located between those who sit around it; the world, like every inbetween, relates and separates men at the same time. ${ }^{35}$

By establishing a space in-between, the world not only provides the physical context within which individuals can move, but also the space out of which their specific, objective worldly interests arise. These interests constitute inter-est, which lies between people and therefore can relate and bind them together. Even though its content is exclusively 'objective,' action retains its agent revealing capacity, since "the public realm, as the common world, gathers us together and yet prevents our falling over each other." ${ }^{36}$ Moreover, publicness depends on natality which initiates the process of collective action and public deliberation. By taking a place in the world that is in-between and concerning about the matters of this world, political action reveals the uniqueness of individuals as well as illuminates the realm of human affairs in its phenomenal reality. ${ }^{37}$

In a nutshell, Arendt's notion of the public realm signifies two meanings of the 'public.' The public realm as the 'space of appearance' arises every time individuals

${ }^{33}$ Arendt, op. cit., supra note 3, p. 52.

${ }^{34}$ Id.

${ }^{35} I d$.

${ }^{36} I d$.

${ }^{37}$ In mass society, Arendt argues, the world in-between has lost its power to gather and separate individuals. Thus, each individual has become entirely private, and in turn, all of them have been "imprisoned in the subjectivity of their own singular experience, which does not cease to be singular if the same experience is multiplied innumerable times." Ibid., p. 58. 
come together in a 'manner of action and speech,' and therefore, it is fragile and transitory. On the other hand, the public realm as the 'world we hold in common' not only provides a physical context in which political action can be actualized, but also by virtue of its durability and permanence, it obtains a temporal context within which individual lives can be revealed, turned into stories and, in turn, attain an 'immortal fame.' By virtue of including multiple, overlapping, and sometimes conflicting public domains and celebrating the contingency of action, Arendt's conceptualization of the public realm challenges Habermas' singular, unitary and comprehensive public sphere which centers around his concern about the 'fragility of the socialized individual.'

\subsection{The Light of the Public Sphere: The Construction of Plurality and Freedom:}

Arendt's conceptualization of the public realm demonstrates the priority of 'the political' and the centrality of action in her political thought. By distinguishing labor, work and action, she accentuates the place of action within the order of the vita activa. In a broad sense, the reason for Arendt to locate action in such a high esteem is her endowment of action with the potential of the realization of the highest human capacities such as freedom and individuality. Action, for her, is the only activity that takes place directly among men without any mediation of things and matters. Therefore, by reference to the synonymousness of the words "to live" and "to be among men," and "to die" and "to cease to be among men" in Roman language, she attempts to stress the correspondence of action to plurality as one of the human condition. ${ }^{38}$ An individual who acts in plurality at the same time - the freedom of choice, as in liberal tradition, or the faculty of liberum arbitrium, as in Christian doctrine, or to take a 'yes' or 'no' position in communicative action, as in Habermas - is an individual who actualizes her or his

${ }^{38}$ Ibid., p. 7. 
freedom in an Arendtian sense. This notion of freedom, then, requires the conceptualization of plurality which is not only a precondition of action that vanishes at the level of 'consensus' for the sake of being able to live together within our multiplicity, but also it is an ever lasting condition in favor of being free.

Plurality, which is one of Arendt's most paradoxical but philosophically revolutionary observation, is "the condition-not only the conditio sine qua non, but the conditio per quam - of all political life." ${ }^{39}$ It has thus several intertwining implications. The simplest meaning signifies multiplicity, to the fact that "men, not Man, live and inhabit in the world." ${ }^{, 40}$ It also denotes the fact that human beings can come together in the "manner of action and speech" and, in turn, establishes the 'world in common' in which they see the common world from different points of view. But, within the scope of this section what is more significant is her emphasis on 'sameness in difference."41 According to Arendt, "[p]lurality is the condition of human action because we are all the same, that is, human in such a way that nobody is ever the same as anyone else who ever lived, lives, or will live." ${ }^{42}$ Accordingly, Arendt identifies two characteristics of plurality: equality and distinctiveness, and sameness and difference. She argues that 'who' we are is unique, and it is this uniqueness that impels us into the realm of politics. Moreover, it is this uniqueness that is shared equally by every individual. In other words, we are equal since each of us is a unique human being. ${ }^{43}$

\footnotetext{
${ }^{39}$ Id. Even though Arendt predominantly treats human plurality as an anthropological datum, and hence, as a condition that does not need to be accounted for, she occasionally traces it back to human natality. In her view, birth and death, natality and mortality are the most general conditions of human existence.

${ }^{40} I d$.

${ }^{41}$ Lisa Jane Disch, Hannah Arendt and the Limits of Philosophy (Ithaca: Cornell University Press, 1994), p. 32.

${ }^{42}$ Arendt, op. cit., supra note 3, p. 8.

43 "Human plurality, the basic condition of both action and speech, has the twofold character of equality and distinction. If men were not equal, they could neither
} 
According to Arendt, the 'who-ness' of an individual cannot be captured by the qualities she possesses, the interests she has, or the sociological categories she belongs to since these are the individual abilities and talents, deficiencies and shortcomings which are traits that all human beings share. These refer therefore to equality rather than distinctiveness, sameness rather than to uniqueness. In this respect, she discerns 'who' somebody is from 'what' somebody is, and defines the former as a 'public identity' which is formed and manifested through acting and speaking in the public realm. But, it should be noted that the disclosure of identity is not a moment by which the self would be known by her peers all at once; rather, it is an endless process in which the self is made and remade through her interactions with fellow citizens in the public realm.

With the rise of 'the social,' the public realm has been identified on the basis of equality, assumed to be inherent in birth and, in turn, the distinctiveness of individuals have become the private matters of concern in the modern world. By excluding the possibilities of action from the public realm and imposing innumerable and various rules upon each of its member, the public sphere, which was reserved for individuality, has been transformed from the sphere of differences into the sphere of sameness implying the "unitedness of many into one." However, the equality taking place in the public realm, as Arendt asserts, should be "the equality of unequals who stand in need of being 'equalized' in certain respects and for specific purposes."44 To frame it somehow differently, she claims that the equality of human beings arises neither from human 'nature' nor it is inherent in our birth, rather it is established by human togetherness. By

understand each other and those who came before them nor plan for the future and foresee those who will come after them. If men were not distinct, each human being distinguished from any other who is, was, or will ever be, they would need neither speech nor action to make themselves understood. Signs and sounds to communicate immediate, identical needs and wants would be enough." Ibid., pp. 175-176.

${ }^{44}$ Ibid., p. 215. 
using an Aristotelian example, she stresses that equality does not rely on the association of two physicians, but between a physician and a farmer; in a broader sense, it depends on association between people who are different and unequal. ${ }^{45}$ In this respect, political equality opposes our equality before birth and death in which no equalizer is required because sameness prevails in any case. The point Arendt attempts to stress about birth and death and everything attesting to sameness is their anti-political and non-worldly character since they are experienced not only in isolation but in utter loneliness in which communication is not possible. It is this samenessthat we encounter in the modern world with the rise of animal laborans who are incapable of action and speech since all members of society primarily concern with sustaining their own lives and those of their families and only activities of this sheer survival are permitted to appear in the public realm.

Briefly, Arendt criticizes modern equality since it generates sameness and conformity through the replacement of action with behavior as the foremost mode of human relationship. As a result, the public sphere has become a sphere in which roles and functions are realized rather than unique selves are revealed. It is my contention that Arendt's critique of modern equality and its generation of sameness and conformity can be applied to Habermas' notion of equality. Like Arendt, Habermas claims that human equality does not stem from 'human nature,' but it is constituted through the 'legal form.' Arendt views this equality as a condition of an endless process in which individuals form and manifest their unique identities, whereas Habermas sees it as a means to reach 'consensus' via argumentation. By defining the rule of moral argumentation and by portraying the 'post-conventional self' as a model performer of this process, he

\footnotetext{
${ }^{45}$ Ibid., pp. 214-215.
} 
transforms the equality of unequals to the equality of equals referred as sameness in the Arendtian terms. As mentioned above, Arendt does not reject the role of law in the public sphere; rather, she disagrees with the inspiration of action via the principles of law.

Habermas conceptualizes the public sphere not on the basis of distinctiveness of individuals, but from their equality that generates sameness. Within the framework of Habermas' theory, this does not create a contradiction; indeed, it is very consistent in itself since he places the identity formation into the cultural and personal aspects of the 'lifeworld' through which individuals are prepared for the public sphere. By locating identity formation prior to entry into the public sphere, he denies self-revelation in the Arendtian sense; indeed, he warns the participants to leave their 'who-ness' behind in favor of argumentation shaped by reference to moral principles and aimed at reaching consensus. In this respect, the only motivations for individuals to enter into politics are the utilization of personal interests and the improvement of political rights; because, unlike Arendt, he does not attribute any other meaning or priority to 'the political,' and he views it as a sphere of consensual resolution of conflicting interests. In doing so, he identifies the public sphere with its own function of system and social integration just like the other spheres of the lifeworld such as economy, administration and family. Therefore, Habermas' conceptualization of 'the political' cannot surmount the 'egocentric notion of the liberal individual' although his notion of the argumentation process aims at reaching a generalizable interest.

Arendt's peculiarity at this point comes from her conceptualization of 'the political' whereby egocentric and instrumental notions of 'the political' prevail. By defining a conditioning relation between politics, freedom and action, she characterizes 
"the raison d'etre of politics [as] freedom, and its field of experience [as] action." ${ }^{46}$ For Arendt, this egocentric and instrumental notion of 'the political' stems from the divorce of action from freedom and, in turn, the equation of freedom with free will. Arendt derives her critique of will, particularly, from Christian philosophy in which the notion of freedom is separated from politics in order to arrive at a formulation stating that one may be a slave in the world but still be free. In this sense, freedom can only be experienced in a complete solitude, between me and myself. By such notion of the two-in-one, the phenomenon of freedom is defined as the capacity to the liberum arbitrium, which arbitrates and decides between two given things, good and evil. Therefore,

in deadly conflict with worldly desires and intentions from which will-power was supposed to liberate the self, the most willing seemed able to achieve was oppression. Because of the will's impotence, its incapacity to generate genuine power, ... the willto-power turned at once into a will-to-oppression. ${ }^{47}$

The equation of freedom with the human capacity to will has created the notion of power identified with oppression, namely, with rule over others. Thus, since then, freedom has not been understood without the notion of sovereignty. Contrary to traditional philosophy, Arendt suggests a notion of freedom which is given to men under the condition of non-sovereignty, because, for her, sovereignty would ruin human plurality. To put it differently, whenever men wish to be sovereign either at the individual level or at the group level, they are forced to submit themselves to the oppression of the will. It could be the individualist will by which the agent force herself or himself or the "general will" of an organized group by which minorities are eliminated by the will of majority. ${ }^{48}$

\footnotetext{
${ }^{46}$ Arendt, op. cit., supra note 9, p. 146.

${ }^{47}$ Ibid., p. 162. For more details see Ibid., pp. 156-165.

${ }^{48}$ Ibid., p. 165.
} 
Habermas' notion of freedom is a continuation of this free will tradition which Arendt persistently opposed. Habermas attempts to develop and expand Kant's notion of freedom as acting under certain kinds of reasons to an intersubjective account of freedom since he raises the question formulated by Rousseau: how could a person be autonomous or self-determining in spite of her inevitable dependence on others? He responds to this question by articulating the 'private' and 'public' autonomy of citizens. For this purpose, he refers both to Kant's individualistic notion of freedom and Rousseau's republican notion of freedom centered around 'general will.' However, Arendt's understanding of freedom is compatible neither with Kant's nor with Rousseau's notion of freedom. On the one hand, Kant's free-willing agent who never appears in the phenomenal world, as Arendt argues, can only create the dictate of the will against the understanding of reason. In other words, the source of freedom is located in a noumenal realm, and the will (qua practical reason) is assimilated to thought. In this sense, the genuine freedom of the will is conditioned by its acting in accordance with the categorical imperative which is an absolute organizing principle of the realm of human affairs. Hence, in its legislative aspect, the will eliminates all references to human plurality. This is the reason why Arendt claims that politics is a mere means for Kant because it only provides the apparatus necessary for the achievement of ends derived from an analysis of moral law. ${ }^{49}$ On the other hand, she opposes the Rousseaudian tradition in terms of its unpolitical character of "general will." According to Arendt, the idea of self-determination by the general will undermines political plurality by implying a single omnipotent ruler. ${ }^{50}$

Such an insufficiency of monological self-determination motivates Habermas to indicate the intersubjective character of human affairs, and to develop a complementary

\footnotetext{
${ }^{49}$ Villa, op. cit., supra note 32, pp. 61-67.

${ }^{50}$ Arendt, op. cit., supra note 9, pp. 163-164.
} 
relation between individual and collective self-determination. For this purpose, he transfers the process of opinion- and will-formation from the inner domain to the public sphere by replacing Kant's monological universalization test of the categorical imperative with a dialogical one-the rule of moral argumentation. ${ }^{51}$ Moreover, he redefines Rousseau's a 'general will,' which dissolves individuals and their interests within collective interest, on the basis of the reflective form of communicative actionargumentation - through which participants can reach 'generalizable interest.' Even though Habermas attempts to reconcile private and public autonomy to surmount the shortcomings of free will tradition, he is unable to do so; because he re-creates domination of the will against understanding through establishing the public sphere on validity claims and defining the procedural norm-testing standards of argumentation.

The nature of truth, from the Arendtian perspective, consists of an element of coercion that risks the plural character of the public sphere since it wishes to prevail over the opinion of the multitude. In the light of the Platonic tradition, she locates truth in the life of philosopher, whereas opinion is in the life of a citizen. She claims that opinion emerges from a 'state of constant flux' within a citizen's life, and a philosopher attempts to stabilize human affairs. Truths, which are beyond agreement, dispute, and consent, therefore can only be destructive of the political life since the public sphere is a realm in which uniqueness of each human being is revealed. Indeed, this self-revelation identifies the public sphere with opinion that is "relative to one's position in the world, and as such

\footnotetext{
${ }^{51}$ It should be noted here that Habermas does not claim that every discourse is moral discourse. Therefore, not the principle of universalizability, but the principle of discourse through which he conceptualizes agents as reason-givers is the principle of all discourses. Even though Habermas differentiates discourses such as objective, normative and evaluative discourses, moral discourse and its principle keep their distinctive and determining place in Habermas' account. This becomes more visible when he transforms the principle of universalizability to the principle of democracy within the political public sphere.
} 
it formulates in speech what dokei moi, what appears to me."52 In her claim, she stresses the 'perspectival character of opinion' and, in turn, claims that only "in matters of opinion, not in matters of truth, our thinking is truly discursive." ${ }^{, 53} \mathrm{My}$ argument is that although normative truth is established through the argumentation process in Habermas' account, he recreates the coercion of truth in the public sphere by defining the procedural standards of argumentation. These principles of argumentation are unquestionable in the sense that they cannot be meaningfully disputed, because they are necessarily presupposed in a process of meaningful argumentation, and for the same reason, they cannot be meaningfully justified by deriving it deductively, and therefore they have a secure, unshakable basis. ${ }^{54}$ This unquestionable character of principles of opinion- and will-formation generates a hegemony of a given paradigm of argumentative rationality. Therefore, all other rhetorics, discourses, and even rationalities, which are opposed to the hegemonic paradigm, will never have the 'force of the better argument.' More succinctly, even though plurality is seen as a precondition of the argumentation, it has been restricted through filtering of opinions by the principle of discourse and the goal of reaching 'consensus' by means of the principle of universalizability.

Furthermore, Habermas' depiction of the telos of a purely communicative politics as a formation of 'common will' falls into an instrumental notion of 'the political' that Arendt diligently avoids. He argues that "the removal of systemic constraints and distortion from communication will result in the more or less natural emergence of a

\footnotetext{
${ }^{52}$ Villa, op. cit., supra note 32, p. 94.

${ }^{53}$ Hannah Arendt, "Truth and Politics," in Between Past and Future: Eight Exercises in Political Thought (New York: Viking Press, 1961), p. 242.

54 This explanation relies on Habermas' usage of the transcendental pragmatics. Jürgen Habermas, Moral Consciousness and Communicative Action (Cambridge, MA: MIT Press, 2001), p. 95.
} 
general interest, public knowledge of which everyone can agree." ${ }^{, 55}$ In doing so, he declares that 'consensus' as an end of politics and, in turn, reproduces the means-ends category of liberal notion of 'the political' by different means. To put it differently, Habermas' position is closer to liberalism since his concern is not to establish the public sphere in which individuals form and manifest themselves and, in turn, cultivate their ethical character, but to provide the public realm in which they can live side by side in their difference without distorting communication. This instrumentalization of 'the political' can be illustrated by the 'new social movements' which are seen as representatives of communicative rationality in Habermas' account. However, I think that the new social movements define themselves in terms of their demands upon the system rather than representing themselves by reference to their distinctiveness-both in their goals and in their action-and, in turn, they waste their unique potential to create power by systemic integration.

Unlike Habermas, Arendt claims that "the reality of the public realm relies on the simultaneous presence of innumerable perspectives and aspects in which the common world presents itself and for which no common measurement or denominator can ever be devised." 56 Plurality therefore is not only an origin but also an achievement of action. That is to say, the public realm is the realm in which both agreement and disagreement, consent and dissent can take place. It is the realm in which action appears as an 'end in itself which finds its meaning in performance that springs from inborn potential of individuals inherent in their birth. It is the realm in which individuals form and reform their 'who-ness' and also make and remake the public sphere itself. The ways in which Arendt depicts the public realm shed light on her conceptualization of morality and

\footnotetext{
${ }^{55}$ Villa, op. cit., supra note 32 , pp. 70-71

${ }^{56}$ Arendt, op. cit., supra note 3, p. 57.
} 
ethics. In the following section, I will illuminate the concepts of morality and ethics from Arendt's point of view, and discuss the implications of different conceptualization of morality and ethics to Arendt's and Habermas' notion of 'the political.'

\subsection{Intertwining of Ethics and Politics in Arendt's Political Thought}

The inspiration for Arendt's conceptualization of morality was her experience of the 'tragedy of democracy' in the twentieth century via totalitarian regimes. For her, this moral breakdown was not a result of human wickedness which failed to recognize and to apply moral truths; rather, it comes from an insufficiency of moral truths as standards to judge what is at stake, because, in Arendt's view, there is no place for an absolute truth in the political life. The separation of morality from 'the political,' according to Arendt, coincides with the rise of Christianity which defines morality in singularity. ${ }^{57}$ While, in Ancient thought, ethics meant 'a set of customs, mores, and manners' which was defined with reference to a common world, it was detached from the public life and transferred from the citizen's ethical conduct to the soul and its salvation in Christian thought. Thus, judgment was reduced to absolute moral rules which derived their power from their religious origin.

Contrary to this depolitical characterization of judgment, Arendt defines judgment as "one of the fundamental abilities of man as a political being insofar as it enables him to orient himself in the public realm, in the common world." ${ }^{, 58}$ More specifically, it is a distinctively political ability, "namely, the ability to see things not only from one's own

\footnotetext{
${ }^{57}$ Hannah Arendt, "Some Questions of Moral Philosophy," Responsibility and Judgment, Jerome Kohn (ed.) (New York: Schocken Books, 2003), p. 50. It is important to note here that Arendt does not differentiate morality from ethics since their original meaning-customs, manners, and habits-is the same. The only difference they have is their origin: 'ethics,' with its Greek origin, and 'morality,' with its Latin origin.

${ }^{58}$ Ibid., p. 221.
} 
point of view but in the perspective of all those who happen to be present." ${ }^{59}$ In doing so, individuals 'enlarge' their own thought to take account others. This 'enlarged mentality' made possible via 'imagination' a means to train one's imagination to 'go visiting. ${ }^{60}$ The equivalent of Arendt's conceptualization of the 'enlarged mentality' seems to be 'ideal role-taking' in Habermas' account, but this is misleading since their interpretation of "thinking in the place of everybody else" is significantly different. In the former,

I form an opinion by considering a given issue from different viewpoints, by making present to my mind the standpoints of those who are absent; that is, I represent them. This process of representation does not blindly adopt the actual views of those who stand somewhere else, and hence look upon the world from a different perspective; this is a question of neither empathy, ... nor of continuing noses and joining a majority but of being and thinking in my own identity where actually I am not. The more people's standpoints I have present in my mind while I am pondering a given issue, and the better I can imagine how I would feel and think if I were in their place, the stronger will be my capacity for representative thinking and the more valid my final conclusions, my opinion. ${ }^{61}$ (Emphasis is added).

${ }^{59}$ Id.

${ }^{60}$ Ibid., pp. 42-43.

${ }^{61}$ Hannah Arendt, "Truth and Politics," in Between Past and Future: Eight Exercises in Political Thought (New York: Viking Press, 1961), p. 241. However, this process of reaching judgment may appear to be 'monological' which is rooted in the perspective of the spectator, rather than the actor. Indeed, this kind of perception involves a distinction between Arendt's early writings and late writings. According to Beiner's distinction, the more Arendt reflected on the faculty of judgment, the more she shifted her emphasis from the actor (vita activa) to the spectator (vita contemplative), from the situated self to the abstract thinking process. However, it is my contention that judgment is not monological in the sense Beiner portrays it. It is true that when people are judging they do it with a certain subjectivity, because each person occupies a place of his own from which he sees the world. But, these judgments are the results of public deliberation, rather than a monological thought experiment. Because, Arendt claims, "the spectator can exist only in plural. [He] is not involved in the act, but he is always involved with fellow spectators." Furthermore, Arendt clearly shows the difference between the actor and the spectator when she states that "[spectator] does not share ... the faculty of novelty with the actor; the faculty they have in common is the faculty of judgment." Following D'Entréves argument, it can be claimed that when Arendt articulates the theory of judgment from the standpoint of the spectator (vita contemplative), she does not intend to exclude the concerns of the actor (vita activa), but rather she contemplate to overcome the shortcomings of subjectivity through representative thinking. For more details see Hannah Arendt, Lectures on Kant's Political Philosophy, Ronald Beiner (ed.) (Chicago: The University of Chicago Press, 1982). 
In the latter, "thinking in the place of everybody else" is actualized through moral agents' attempts to "put themselves in each other's shoes" in discussing whether a proposed norm is fair to all. This 'ideal-role taking' necessitates the individual peeling away her or his identity and adopting a moral point of view in order to reach a 'consensus. ${ }^{62}$ For Arendt, such a separation of individual from her or his own location in the "world in common' cannot even be an issue because it generates a sameness in the public world and, in turn, negates the ways in which the 'extraordinary' is called into existence. More simply, the plurality of the public sphere is sacrificed for the sake of reaching a 'consensus.'

In contrast, Arendt's concept of judgment relies on a 'potential' agreement with others. In adopting Kant's judgment of taste, she asserts that "the judging person can only 'woo the consent of everyone else' in the hope of coming to an agreement with him eventually."63 This potential agreement is grounded in 'common sense' which "discloses the nature of the world insofar as it is a common world" whereby subjective opinions can adjust themselves to an objective world which we have in common and share with others. Moreover, since such judgment is concerned with the world in its appearance it must liberate itself from both the needs of life and the moral interests of the self. ${ }^{64}$ Arendt thus endows judgment with a certain validity which rests on its 'communicability' and its accordance with 'the community sense of rightness.' Although both Arendt and Habermas identify 'communicability' as a criteria for validity of judgment, Arendt's conceptualization of validity, unlike Habermas", "is never universally valid;" rather it is

\footnotetext{
${ }^{62}$ Habermas, op. cit., supra note 57, pp. 121-129.

${ }^{63}$ Hannah Arendt, "The Crisis in Culture: Its Social and Its Political Significance," in Between Past and Future: Eight Exercises in Political Thought (New York: Viking Press, 1961), p. 222.

${ }^{64}$ The elevation of men above needs of life and self is called 'disinterestedness.' Id.
} 
sensitive to contexts and particularities since there is no objective or cognitive grounds for validation of political judgment. ${ }^{65}$

In light of Arendt's theory of action and theory of judgment, it can be claimed that, politics and ethics are intertwined in her account. Since the public realm is portrayed as a realm through which individuals form and manifest their identities, it appears as a sphere in which individuals cultivate their character in the Aristotelian sense. Furthermore, by referring to 'common sense' for validity of judgment, she indicates the centrality of the 'world in common' rather than the 'self' and, in turn, judgment emerges as an "activity of a truly cultivated mind." However, it is important to note that Arendt's conceptualization of 'the political' goes further than Aristotelian notion of 'the political' because she achieves to establish a dialectical relation between individuality and communality through her emphasis on distinctiveness of an individual as well as the necessity of 'act in concert' to actualize the potential of power. Furthermore, in Arendt's view, what people have in common is not the telos of a shared world like Aristotelian politics, but the world itself which is formed and reformed by political action, and in which individuals are constituted and reconstituted. This dialectical relation, Amy Allen argues, provides an alternative notion of solidarity which does not relies on "a shared identity if that identity is understood as resting on an inherent sameness, be it a shared essence, a shared experience of oppression..." or on an assumed "empathy and concern for the well-being of one's neighbor" in Habermasian terms. ${ }^{66}$ In other words, solidarity is based neither on a 'community of feelings,' nor on a 'community of communicative rationality,' but on a 'community of action.'

\footnotetext{
${ }^{65}$ Ibid., p. 221.

${ }^{66}$ Amy Allen, "Solidarity After Identity Politics: Hannah Arendt and the Power of the Feminist Theory," Philosophy and Social Criticism 25 (1) (1999), p. 107. Jürgen Habermas, "Morality and Ethical Life: Does Hegel's Critique of Kant Apply to Discourse Ethics?" Northwestern University Law Review 83 (1989), p. 43.
} 
Arendt argues that our given identities i.e. being Jewish, Indian, womaen, consist of coercive features like all other truths. ${ }^{67}$ Since the public sphere is a realm of plurality the "unitedness of many into one is basically antipolitical." She sees being a member of an identity group as a political fact which is undeniable, and to attempt to deny it is dangerous and deluded. Therefore, if these identities are 'under attack' this attack must be resisted not on the basis of being human, but on the basis of the identity attacked. In contrast, Habermas relies on his notion of solidarity on perspective-taking through which empathy becomes a procedure of reaching a reasoned agreement. In this sense, solidarity is seen as a result of the rationalization process of society and individual. Referring to the same rationalization process for each individual and each society against their particularities, the basis of solidarity is defined by reference to their sameness stemming from the adoption of the decentred understanding of the world. Moreover, Arendt locates political action at the center of her notion of solidarity as opposed to Habermas' assumed notion of solidarity. In her claim, she does not refer to any 'shared essence' which is inherently exclusionary and repressive, but a 'shared commitment' of distinct individuals to act together. In other words, solidarity grows out of acting in concert; rather than of fixed and natural categories. Her conceptualization of solidarity, as Allen suggests, makes it possible to "resist in terms of the identity that is under attack." 68 For instance, one does not need to 'be' a woman to resist subordination of women, or to 'be' a Kurd to resist the oppression of Kurdish people. Thus, she "allows us to imagine non-repressive, nonexclusionary, but solidary forms of collectivity."

\footnotetext{
${ }^{67}$ Arendt, op. cit., supra note 53, pp. 232-243.

${ }^{68}$ Allen, op. cit., supra note 66, p. 112.

${ }^{69}$ Ibid., p. 102.
} 
In summary, Arendt does not differentiate morality and ethics in her political thought; indeed, she indicates that it is not their meaning, but only their origin which is different. Therefore, she uses these two terms interchangeably. It is my contention that, in her view, morality and politics are intertwined and therefore, the public realm emerges as a realm in which individuals not only form and transform their own identities through action and speech but they also shape and reshape the public realm itself. By locating the world in the centre of morality, she removes the veil that is hiding the Aristotelian ethical basis of her thought. Contrary to Arendt, Habermas makes a sharp distinction between morality and ethics, and establishes the public sphere with reference to the moral principles to eschew the fragility of human affairs and the vulnerability of communication forms. In doing so, he not only reproduces the 'means-ends' category of liberal notion of 'the political' but he also restricts plurality of the public sphere. 


\section{Conclusion}

Man's inability to rely upon himself or to have complete faith in himself (which is the same thing) is the price human beings pay for freedom; and the impossibility of remaining unique masters of what they do. of knowing its consequences and relying upon the future, is the price they pay for plurality and reality, for the joy of inhabiting together with others a world whose reality is guaranteed for each by the presence of all.

Hannah Arendt

Can we be masters of our actions? Are we able to assume all the consequences and side effects that action creates? Are we capable of avoiding the ripple effect of our acts? These are some of the questions that can reflect our understanding of 'the political' in relation to our responses to them, as 'yes' or 'no.' It can be said that Habermas attempts to keep all the responses to these questions within the scope of 'yes' with respect to his social evolutionist attitude and his cognitivist perspective. His goal is to shield the socialized individual from the threats of communicative forms of life. For this reason, he draws the boundaries of the public sphere by accounting for moral principles that demonstrate 'what' can enter into the argumentation process and 'how' its validity can be tested. This relation between morality and politics is supported by institutionalized procedures of legitimate lawmaking which transforms public opinion into binding decisions. In doing so, he tends to render the consequences and side effects of political action predictable and, in turn, controllable by reference to a moral subject who is guided by universal ethical principles - the equality of human rights and respect for the dignity of human beings - and who enters into the argumentation process to test her or his validity claims with respect to the principle of universalizability. In this sense, the price to pay for rendering consequences and side effects of political actions predictable, as Arendt persuasively expressed in the quotation above, is human plurality and the reality 
of the 'world we hold in common' since the equality of equals generates sameness and conformity and, in turn, the public sphere loses its place as a table which gathers us together and separates us. It is my contention that the loss of human plurality and reality of the 'world in common' is a big price to pay if we accept that the public sphere is the realm in which we can form and manifest our identities; if we see this sphere as a realm where we become free through our actions and speech. Furthermore, it is a big price to pay since Habermas' public sphere never quite comes down on earth. More specifically, the rise of nationalism in Europe, which might be a possible place for the actualization of Habermasian public sphere, challenges not only the ontogenesis of the speaker and world perspectives but also the theory of social evolution.

Habermas' limited conceptualization of 'the political' can be robustly challenged from an Arendtian perspective which relies on an acceptance of the tragedy of democracy.' By celebrating the contingent character of action, she keeps the doors of the public sphere open to an unexpected, extraordinary and radiant political action. This does not mean that the public sphere is neither a sphere of 'war,' nor a sphere of disagreements and dissent; rather it is protected by some institutions and law in order to provide a permanence and durability for the futility of human existence. Unlike Habermas, Arendt is aware of the limitedness of human artifacts. She therefore finds a balancing factor in the public sphere and praxis. In this sense, she brings forth the old virtue of moderation and judgment both of which demonstrate an intertwining of politics with ethics. Arendt's conception of 'the political' therefore does not consist of abstract autonomous moral subjects, rather it consists of tangible, moral or ethical human beings. It is not restricted by moral principles whose reality cannot be questioned, but is the sphere in which 
"everybody sees and hears from a different position," it is the sphere which relies on "simultaneous presence of innumerable perspectives and aspects ... for which no common measurement or denominator can ever be devised."

\footnotetext{
' Hannah Arendt, The Human Condition (Chicago: University of Chicago Press, 1958) (second edition, 1998), p. 57.
} 


\section{Bibliography}

Arendt, H., The Human Condition (Chicago: University of Chicago Press, 1958) (second edition, 1998).

Arendt, H., Between Past and Future: Eight Exercises in Political Thought (New York: Viking Press, 1961).

Arendt, H., Lectures on Kant's Political Philosophy, Ronald Beiner (ed.)(Chicago: Chicago University Press, 1982).

Arendt, H., "Philosophy and Politics," Social Research, 57 (1) (1990).

Arendt, H., Responsibility and Judgment, Jerome Kohn (ed.) (New York: Schocken Books, 2003).

Aristotle, The Ethics of Aristotle (The Nicomachean Ethics), J. A. K. Thomson (trans.) (New York: Penguin Books, 1979).

Ashenden, S., 'Questions of Criticism: Habermas and Foucault on Civil Society and Resistance,' in Foucault Contra Habermas, Samantha Ashenden and David Owen (ed.) (London \& Thousand Oaks \& New Delhi: SAGE Publication, 1999).

Baynes, K., "Democracy and the Rechsstaat: Habermas' Faktizität und Geltung," in The Cambridge Companion to Habermas, Stephen K. White (ed.) (Cambridge: Cambridge University Press, 1995).

Benhabib, S., Situating The Self: Gender, Community, and Postmodernism in Contemporary Ethics (Cambridge: Polity Press, 1992).

Berger, J., "The Linguistification of the Sacred," in Communicative Action: Essay's on Jürgen Habermas's Theory of Communicative Action, Alex Honneth \& Hans Joas (eds.), Jeremy Gaines \& Doris L. Jones (trans.) (Cambridge: The MIT Press, 1991).

Bernstein, R. J., "The Retrieval of the Democratic Ethos," in Habermas on Law and Democracy: Critical Exchange, Michael Rosefeld \& Andrew Arato (eds.) (Berkeley: University of California Press, 1998).

Beiner R., "Do We Need a Philosophical Ethics? Theory, Prudence, and the Primacy of Ethos," in Action and Contemplation: Studies in the Moral and Political Thought of Aristotle, Robert C. Bartlett and Susan D. Collins (eds.) (New York: State University of New York Press, 1999).

Buchwalter, A., "Habermas, Hegel, and the Concept of Law," in Discourse and Democracy: Essays on Habermas's Between Facts and Norms (Albany: State University of New York Press, 2002). 
Calhoun, C., "Introduction: Habermas and the Public Sphere," in Habermas and the Public Sphere, Craig Calhoun (ed.) (Cambridge, Mass: MIT Press, 1992).

Calhoun, C., "Plurality, Promises, and Public Space," in Hannah Arendt and the Meaning of Politics, Craig Calhoun and John McGowan (eds.) (London: University of Minnesota Press, 1997).

Castoriadis, C., 'Power, Politics, Autonomy,' in Philosophy, Politics, Autonomy: Essays in Political Philosophy, D. A. Curtis (ed.) (New York: Oxford University Press, 1997).

Castoriadis, C., "Democracy as Procedure and Democracy as Regime," in Constellations 4 (1) (1997).

Castoriadis, C., Castoriadis Reader, D. A. Curtis (trans. and ed.) (Oxford and Malden: Blacwell Publisher, 1991).

Chambers, S., "Discourse and Democratic Practices," in The Cambridge Companion to Habermas, Stephen K. White (ed.) (Cambridge: Cambridge University Press, 1995).

Dean, M., "Normalising Democracy: Foucault and Habermas on Democracy, Liberalism and Law," in Foucault Contra Habermas, Samantha Ashenden and David Owen (eds.) (London: SAGE Publication, 1999).

D'Entréves, P. M., “Freedom, Plurality, Solidarity: Hannah Arendt's Theory of Action," Philosophy and Social Criticism 15 (4) (1989).

D'Entréves, P. M., The Political Philosophy of Hannah Arendt (London: Routledge, 1994).

Disch, J. L., Hannah Arendt and the Limits of Philosophy (Ithaca: Cornell University Press, 1994).

Fraser, N., "What is Critical about Critical Theory? The Case of Habermas and Gender," New German Critique, 35, Special Issue on Jürgen Habermas (Spring-Summer, 1985).

Fraser, N., "Rethinking the Public Sphere: A Contribution to the Critique of Actually Existing Democracy," in Habermas and the Public Sphere, Craig Calhoun (ed.) (Cambridge, Mass: MIT Press, 1992).

Habermas, J., Theory and Practice, John Viertel (trans.) (Boston: Beacon Press, 1973).

Habermas, J., Legitimation Crisis, Thomas McCarthy (trans.) (Boston: Beacon Press, 1976).

Habermas, J., The Theory of Communicative Action, Vol. I., Thomas McCarthy (trans.) (Boston, Beacon Press, 1984). 
Habermas, J., "Hannah Arendt: On the Concept of Power," in Philosophical-Political Profiles, Frederick G. Lawrence (trans.) (Cambridge: MIT Press, 1985).

Habermas, J., Autonomy and Solidarity: Interviews with Jurgen Habermas, Peter Dews (ed.) (London: Verso, 1986).

Habermas, J., "Law as Medium and Law as Institution," in Dilemmas of Law in the Welfare State, G. Teubner (ed.) (New York: de Gruyter, 1986).

Habermas, J., Theory of Communicative Action, Vol. II., Thomas McCarthy (trans.) (Boston, Beacon Press, 1987).

Habermas, J., The Structural Transformation of the Public Sphere, T. Burger (trans.) (Cambridge, Polity Press, 1989).

Habermas, J., "Morality and Ethical Life: Does Hegel's Critique of Kant Apply to Discourse Ethics?" Northwestern University Law Review 83 (1989).

Habermas, J., Moral Consciousness and Communicative Action (Cambridge, MA: MIT Press, 1991) (seventh edition).

Habermas, J, Justification and Application: Remarks on Discourse Ethics, Ciaran Cronin (trans.) (Cambridge: MIT Press, 1993).

Habermas, J., "Three Models of Democracy,” in Constellation 1 (1994).

Habermas, J., Between Facts and Norm: Contribution to a Discourse Theory of Law and Democracy, William Regh (trans.) (Cambridge: Polity Press, 1996).

Habermas, J., "Reply," in Habermas on Law and Democracy: Critical Exchanges, Michel Rosenfeld and Andrew Arato (eds.) (Berkeley: University of California Press, 1998).

Habermas, J., "A Conversation about Questions of Political Theory," in Discourse and Democracy: Essays on Habermas's Between Facts and Norms, R. Von Schomberg, and Kenneth Baynes (eds.) (Albany: State University of New York Press, 2002).

Habermas, J., "Public Space and Political Public Sphere-the biographical roots of two motifs in my thought," Commemorative Lecture, Kyoto Nov.11 (2004).

Hanks, C., Refiguring Critical Theory: Jürgen Habermas and the Possibilities of Political Change (Boston: University Press of America, 2002).

Honneth, A., The Critique of Power: Reflective Stages in a Critical Social Theory, Kenneth Baynes (trans.) (Cambridge, Mass: MIT Press, 1991). 
Honneth, A., The Struggle for Recognition: The Moral Grammar of Social Conflicts, Joel Anderson (trans.) (Cambridge, Mass: MIT Press, 1996).

Kalyvas, A., "The Politics of Autonomy and the Challenge of Deliberation: Castoriadis contra Habermas," Thesis Eleven 64 (February 2001).

Kant, I., Fundamental Principles of the Metaphysics of Morals, T. K. Abbott (trans.) (New York: Prometheus Books, 1988).

Kant, I., "On the Disagreement between Morals and Politics in Relation to Perpetual Peace," in Kant: Political Writings, Hans Reiss (ed.), H. B. Nisbet (trans.) (Cambridge: Cambridge Press, 1991).

Maus, I., "Liberties and Popular Sovereignty: On Jürgen Habermas's Reconstruction of the System of Rights," in Discourse and Democracy: Essays on Habermas's Between Facts and Norms, René Von Schomberg and Kenneth Baynes (eds.) (Albany: State University of New York Press, 2002).

McCarthy, A. T., The Critical Theory of Jürgen Habermas (Cambridge: MIT Press, 1978).

McCarthy, T., "Practical Discourse: On the Relation of Morality to Politics," in Ideals and Illusions: On Reconstruction and Deconstruction in Contemporary Critical Theory (Cambridge: The MIT Press, 1991).

McCarthy, T., "Reason and Rationalization: Habermas "Overcoming" of Hermeneutics," in Ideals and Illusions: On Reconstruction and Deconstruction in Contemporary Critical Theory (Cambridge: The MIT Press, 1991).

McCarthy, T., "Legitimacy and Diversity: Dialectical Reflections on Analytical Distinctions," in Habermas on Law and Democracy: Critical Exchange, Michael Rosenfeld and Andrew Arato (eds.) (Berkeley: University of California Press, 1998).

Oakeshott, M., "Rationalism in Politics," in Rationalism and Politics and Other Essays (London: Methuen \& Co Ltd., 1962).

O'Neill, S., "Morality and Ethical Life," in Impartiality in Context: Grounding Justice in a Pluralist World (Albany: State University of New York Press, 1997).

Owen, D., "Genealogy as Exemplary Critique: Reflections on Foucault and the Imagination of the Political," Economy and Society, 24 (4) (1995).

Owen, M., Between Reason and History: Habermas and the Idea of Progress (Albany: State University of New York Press, 2002). 
Rehg, W., "Moral Discourse and Conceptions of the Good Life," in Insights and Solidarity: A Study in the Discourse Ethics of Jürgen Habermas (Berkeley: University of California, 1994).

Rehg, W., \& Bohman, J., "Discourse and Democracy: The Formal and Informal Bases of Legitimacy in Between Facts and Norms," in Discourse and Democracy: Essays on Habermas's Between Facts and Norms, René Von Schomberg and Kenneth Baynes (eds.) (Albany: State University of New York, 2002).

Sandel, J. M., "The Procedural Republic and the Unencumbered Self," Political Theory 12 (1) (February 1984).

Shabani, O. A. P., Democracy, Power and Legitimacy: The Critical Theory of Jürgen Habermas (Toronto: University of Toronto Press, 2003).

Villa, R., D., Arendt and Heidegger: The Fate of the Political (Princeton: Princeton University Press, 1996).

Volpi, F., "The Rehabilitation of Practical Philosophy and Neo-Aristotelianism," in Action and Contemplation: Studies in the Moral and Political Thought of Aristotle, Robert C. Bartlett and Susan D. Collins (eds.) (New York: State University of New York Press, 1999).

Tully, J., 'To Think and Act Differently: Foucault's Four Reciprocal Objection to Habermas' Theory,' in Foucault Contra Habermas, Samantha Ashenden and David Owen (eds.) (London: SAGE Publication, 1999).

Young, M. I., "Impartiality and the Civic Public: Some Implication Feminist Critiques of Moral and Political Theory," in Feminism as a Critique: Essays on the Politics of Gender in Late-Capitalist Societies, Seyla Benhaib and Drucilla Cornell (eds.) (Oxford: Polity Press, 1987).

White, K. S., The Recent Work of Jürgen Habermas (Cambridge: Cambridge University Press, 1988). 